AperTO - Archivio Istituzionale Open Access dell'Università di Torino

\title{
Retirement of the self-employed in the Netherlands
}

\section{This is a pre print version of the following article:}

Original Citation:

Availability:

This version is available http://hdl.handle.net/2318/1740788

since 2020-06-09T12:43:38Z

Published version:

DOI:10.1007/s11187-019-00179-0

Terms of use:

Open Access

Anyone can freely access the full text of works made available as "Open Access". Works made available under a Creative Commons license can be used according to the terms and conditions of said license. Use of all other works requires consent of the right holder (author or publisher) if not exempted from copyright protection by the applicable law. 


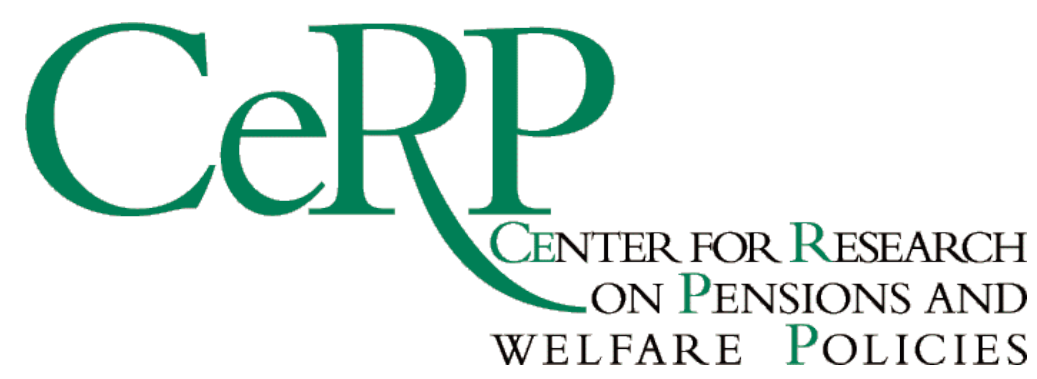

Working Paper 182/18

\title{
LABOUR MARKET DECISIONS OF THE SELF-EMPLOYED IN THE NETHERLANDS AT THE STATUTORY RETIREMENT AGE
}

\author{
Amparo Nagore García \\ Mariacritina Rossi \\ Arthur van Soest
}




\title{
Labour Market Decisions of the Self-Employed in the Netherlands at the Statutory Retirement Age
}

\author{
Amparo Nagore García, LISER ${ }^{1}$ \\ Mariacristina Rossi, University of Turin, CeRP-CCA \& Netspar ${ }^{2}$ \\ Arthur van Soest, Tilburg University \& Netspar ${ }^{3}$
}

\begin{abstract}
We investigate retirement decisions of the self-employed in the Netherlands using administrative data. We focus on the time period around which individuals reach the statutory retirement age (SRA, 65 years in most cases). After the statutory retirement age, each Dutch resident receives the Old Age State Pension annuity (AOW), providing an income at the subsistence level. Both the timing and the magnitude of this state pension are well known in advance. According to a standard leisure/consumption trade-off life cycle model, receiving AOW should therefore have no impact on labour supply choices. While employees often face the demand side restriction of mandatory retirement, this does not apply to the self-employed. We investigate whether retirement and earnings of the self-employed change at the SRA and whether any such changes vary with, e.g., the level of financial wealth. We find a peak in retirement when self-employed reach the SRA. The evidence suggests that the benchmark of retiring at 65 is acting as a driver, due to behavioural features like anchoring or a social norm.
\end{abstract}

Key words: Life cycle model, retirement decision, reference point, social norm JEL: D91, D31, J26, L26

\footnotetext{
${ }^{1}$ Amparo Nagore Garcia, Campus Belval Maison, des Sciences humaines, 11, Porte des Sciences, L-4366 Esch-Sur-Alzette ; E-mail: amparo.nagore@liser.lu

${ }^{2}$ Mariacristina Rossi, University of Turin, CeRP-CCA and Netspar; E-mail: mariacristina.rossi@unito.it

${ }^{3}$ Arthur van Soest: Netspar and Department of Econometrics and Operations Research, Tilburg University, PO Box 90153,5000 LE, Tilburg, The Netherlands; E-mail: avas@uvt.nl

This paper uses non-public microdata provided by Statistics Netherlands, made available for scientific research under certain conditions (contact microdata@cbs.nl for further information). Data access is funded by Netspar through the theme project Uncertainty over the life-cycle: Implications for pensions and savings.
} 


\section{Introduction}

In the Netherlands, a State Pension income (AOW) at the subsistence level (currently approximately $€ 1,160$ for individuals living alone and $€ 800$ for individuals in couples) is given to everyone who has always been a Dutch resident and has reached the Statutory Retirement Age (SRA, from now on), irrespectively of employment status, labour market history, or other income. More specifically, the amount only depends on household composition (unmarried and living alone versus married or living together) and the number of years of residence in the country (declining by $2 \%$-points for every year not lived in the Netherlands).

For employees, the SRA usually coincides with their age of mandatory retirement. For the self-employed, however, eligibility for the state pension does not impose any institutional constraints for working -- they can choose their working hours before and after the SRA on the basis of their preferences (given their health status, family situation, etc.). This makes it interesting to study if (and if so, how) their labour supply responds to reaching the SRA. According to a standard life cycle model, in absence of demand side restrictions, we would expect that the selfemployed gradually reduce their work intensity due to age-related changes in preferences, health, and productivity. Reaching the SRA as such should have no (discontinuous) impact on retirement or labour supply unless individuals respond to cash-receipt (see Borella, Fornero and Rossi, 2009 and Rossi and Trucchi, 2016), e.g. due to liquidity constraints, or respond behaviourally, e.g. since the SRA acts as an anchor or benchmark age (see, e.g., Behagel and Blau, 2012, or Vermeer, 2016).

A large strand of literature has focused on whether cash receipts change consumption and saving patterns. Were people rational and without financial restrictions, they should react to unpredicted shocks to income only, and consumption should be based on their permanent income. A predicted change in income or wealth should not generate a change in consumption, as it was already incorporated in permanent income. Hence the timing at which income is cashed should not matter for consumption decisions. Over-sensitivity to income can, however, be easily explained in a rational life-cycle model if individuals are liquidity constrained (Deaton, 1992; Guariglia and Rossi, 2002). In this case, the best consumption path someone can afford may just be to consume their current income. When income rises, individuals can get closer to the unrestricted optimum by increasing their consumption. 
While the reaction of consumption to income changes is well documented, longitudinal studies of what happens with leisure and labour supply decisions when non-labour income changes are less common. The economic reasoning is the same as with consumption. If utility depends on both leisure and consumption, individuals choose their optimal leisure and consumption levels on the basis of lifetime full income, irrespective of the timing when income is received. Since the income change at SRA is known ex ante and should therefore be fully anticipated, we should, in absence of other changes at SRA such as demand side restrictions, observe no labour supply response, or, specifically, no peak in retirement at SRA, except for those who are liquidity constrained and cannot rely upon their wealth to smooth leisure and consumption. Liquidity constraints might constrain individuals to work until they receive the monthly state pension when reaching SRA.

Things would be very different if the income change were unexpected (see, e.g., Brown, Coile and Weisbenner, 2010), in which case we would expect a response due to a change in (expected) permanent income. In the empirical literature on the life cycle, mainly focused on the effect of predicted changes in consumption and saving patterns, findings tend to confirm the theory that the realisations of fully predicted income changes have little effect on economic decisions (see, e.g., Borella, Coda Moscarola and Rossi, 2014). Brown, Coile and Weisbenner (2010) find that the relation between inheritance receipt and earlier retirement is stronger when the inheritance is unexpected.

Since the AOW amount does not depend on life-time earnings, it is much higher in relative terms for low income and low wealth groups than for the wealthy. Moreover, the wealthy will typically not face liquidity constraints. The ex-ante expectation is therefore that the rich should react less to the AOW receipt than the poor. Excess sensitivity by the richest to receiving AOW could still be explained by behavioural phenomena, such as social norms: As most employees retire at the SRA of 65 , this could set a social norm that may also influence workers who do not face mandatory retirement, liquidity constraints, or other standard economic arguments for retiring at the SRA (see, e.g., Behaghel and Blau, 2012, for the US, Kautonen, Tornikoski and Kliber, 2011, for Finland, or Van Erp, Vermeer and van Vuuren, 2014, and Vermeer, 2016, for the Netherlands). 
Self-employed workers represent a substantial segment of the Dutch working population, $15.15 \%$ in $2011 .{ }^{4}$ This proportion increases to $50 \%$ of those between 65 and 74 years old doing paid work. ${ }^{5}$ Self-employed, unlike employees, do not face a compulsory retirement age and do not have to accommodate their preferences for working to their employer, giving them more freedom to adapt their working choices to their own preferences, particularly when they get older. Retirement decisions of self-employed, in other words, are entirely made by the individuals themselves and not subject to any pension or benefit rule related to exit from the labour market. Self-employed are entitled by law to the State Pension, which is independent of the contributions paid during their working life. The state pension is a pay-as-you-go pension, funded by income tax contributions of those who have not yet reached the SRA (17.9\% of income in the lowest two tax brackets). For those who have been self-employed all their life, any other form of pension comes from voluntary private (pension) savings, e.g. a third pillar pension.

Our aim is to analyse the effect of SRA receipt on retirement decisions for those who have no constraints in their choices by their employers. For this reason the self-employed represent the best sample to run our analysis. We additionally select, within the broad category of all selfemployed, those who did not have employment spells as employees. This rules out workers who have been self-employed only temporarily and may have an occupational pension arrangement where the SRA plays some role. Moreover, we only consider the largest category (around $60 \%)^{6}$ of self-employed: the entrepreneurs. This group has the largest freedom of making their own paid work choices.

In addition, to rule out possible other factors shaping retirement choices, we only select entrepreneurs who are unmarried. Studying self-employed retirement in couples is more complicated, not only because of joint decision making but in our case also because of the effects of the partner allowance: a state pension for non-working partners below SRA whose partner has already reached SRA (in place until 2015).

\footnotetext{
4 Source: OECD (2017), Self-employment rate (indicator). doi: 10.1787/fb58715e-en. This indicator includes the employment of employers, workers who work for themselves, members of producers' co-operatives, and unpaid family workers. All persons who work in corporate enterprises, including company directors, are considered to be employees.

${ }^{5}$ Source: Eurostat. http://appsso.eurostat.ec.europa.eu/nui/show.do?dataset=Ifst_r_Ife2estat\&lang=en

${ }^{6}$ Excluding directors.
} 
We will use a unique administrative dataset including the whole population of selfemployed in The Netherlands, containing detailed information on demographic characteristics, job characteristics, incomes and household wealth. The use of this administrative dataset distinguishes this study from many previous ones on self-employment that used survey data with small samples. The use of a rich administrative dataset is especially relevant when analysing the behaviour of the self-employed given their high heterogeneity.

We model the transitions out of self-employment into wage employment or retirement using a discrete hazard model with a multinomial logit functional form. Controlling for a continuous age function, the effect of reaching the SRA (and receiving AOW) on the transition probability into retirement is our main parameter of interest (the labour supply change at the extensive margin).

We find an overreaction to reaching the eligibility age and receiving the state pension. This suggests that people are, contrary to theoretical predictions, oversensitive to anticipated changes in non-labour income. This evidence can be reconciled with the social norm of retiring at 65 , which indeed acts as a driver for employees since it is the mandatory retirement age. In line with our predictions, our results show that the retirement decisions of the richer groups of self-employed are less sensitive to receiving the state pension than those of the less wealthy self-employed.

Older self-employed may prefer to retire gradually and reduce hours worked with age. To examine the impact of reaching the SRA on labour supply at the intensive margin, we also estimate some models explaining (positive) profits, as a proxy for working effort (since we do not observe hours worked). We find that profits fall gradually from the year after reaching the SRA onwards. For men, the decline is largest in the lowest part of the wealth distribution, in line with the prediction of the standard life cycle model with liquidity constraints. For women however, the strongest decline of profits after reaching the SRA is in the third wealth quartile. These gender differences might be due to the fact that women are more influenced by social norms or age anchors than men.

To sum up, we contribute to the empirical literature of the life cycle model (e.g. Brown Coile and Weisbenner, 2010) by testing empirically one of the predictions of the Life cycle model in a clean way. We add evidence to the scarce literature on retirement of self-employed (e.g. 
Parker and Rougier, 2007; Hochguertel, 2010; Schuetze, 2015; Heim,2015) analysing the labour supply at the extensive and intensive margin of older entrepreneurs and exploring heterogeneous effects that vary with wealth and gender.

The remainder of the paper is organized as follows. Section 2 presents a brief review of the literature. Section 3 explains the main characteristics of the Dutch pension system. Section 4 describes the data. In section 5 we present the econometric framework of transitions from selfemployment to retirement and profits. Section 6 discusses the main results. Conclusions are drawn in section 7 .

\section{Motivation and Previous studies}

Do people respond to (dis)incentives to work depending on their financial availability and, hence, their socio-economic status? Receiving cash, well known in advance both in timing and in its magnitude, should normally not generate any effect on the behaviour of rational individuals who maximize expected utility over their life cycle. Standard economic life-cycle models suggest that anticipated cash receipt should not be a channel at work as people interiorize this additional exogenous income in their intertemporal planning. However, if people are liquidity constrained, having cash available can act as a driver in economic decisions and we could observe a reaction at the time of the cash receipt. Using (lack of) wealth as a proxy for liquidity constraints, our ex-ante expectations are that individuals with low wealth might respond to such a cash receipt by reducing their labour supply, while no response is expected for high wealth individuals.

The impact of wealth on labour choices is potentially an important channel per se. Johansson (2000) and Nykvist (2008) find a positive relation between wealth and entrepreneurship, in line with the notion that liquidity constraints may hamper entry into selfemployment. Hurd (1990) finds a positive association between retirement decisions and financial wealth. In contrast, Zissimopoulos and Karoly (2007) surprisingly find that workers belonging to the second and third quartiles of the distribution of Social Security Wealth (SSW) retire later than those in the poorest quartile. According to Atalay and Barrett (2016), pension reforms are likely to have more consequences on labour supply for families with low liquid wealth, due to the inability to borrow against future expected SSW. 
Brown, Coile and Weisbenner (2010) explore the role played by liquidity constraints for the response to the (expected or unexpected) receipt of an inheritance and do not find a consistent pattern of stronger effects for liquidity-constrained households. They argue that this might be due to the difficulty to find a good proxy for liquidity constraints, given that these might be endogenously determined with inheritance expectations. In a similar vein, Picchio, Suetens and van Ours (2017) look at the impact of winning a lottery on labour supply, finding, as expected, a negative effect. Georgellis, Sessions and Tsitsianis (2005) analyse the effects of different types of windfall gains on entries into and exits out of self-employment. They find that windfalls increase the probability of a transition into self-employment at a decreasing rate and reduce the survival rate in self-employment, particularly if the windfall gain has the form of an inheritance. Georgellis, Sessions and Tsitsianis (2005) focus on exogenous and unexpected changes in wealth. Our goal is, instead, to study the consequences of an exogenous but expected change in income - the state pension received after the statutory retirement age.

The life cycle model is a powerful framework used to model retirement decisions, however, the persistence of large spikes in exits from labour force at the eligibility age of Social Security benefits can not be fully explained in this framework (Behagel and Blau, 2012). Other explanations in the behavioural economics framework have been explored, such as reference dependence with loss aversion, advice from the Social Security Administration, and social norms. Behagel and Blau (2012) and Vermeer (2016) find that the manner of framing the standard retirement age influences the behavioural response, for instance, conforming the social norm or the reference point. Seibold (2017) uses a model of retirement with reference-dependent utility to interpret the effect of framing on retirement. In addition, Kautonen, Tornikoski and Kliber (2011) find that social norms, particularly age norms, exert a significant influence on entrepreneurial intention in the third age.

In the entrepreneurship literature, a number of studies analyse the transitions into and out of self-employment and their determinants, considering socio-economic characteristics (e.g. (Johanssson, 2000; Zissimopoulos and Karoly, 2007; Minola, Criaco and Obschonka, 2016) and behavioural factors (Caliendo, Fossen and Kritikos, 2014). Only a few studies focus on older workers and retirement (e.g. Heim, 2015 and Parker and Rougier, 2007). 


\section{The Three Pillars of the Dutch Pension System}

As in many European countries, the Dutch pension system consists of three pillars: a state pension, (mandatory) occupational pensions, and individual private pensions.

\section{First pillar: AOW}

The first pillar is the state pension (AOW, Algemene Ouderdoms Wet $^{7}$ ) that aims to provide a basic income (linked to the minimum wage) for everyone who has reached the statutory retirement age (SRA). ${ }^{8}$ Its financing scheme is a Pay-as-you-go system. Everyone who has been a resident in the Netherlands from age SRA-50 until SRA is eligible for AOW after reaching the SRA; each year, $2 \%$ of the full public pension benefit is accumulated. The rules for eligibility and for the amount of AOW are very easy and published widely. Thus every Dutch citizen who makes a small effort to collect the information can fully anticipate receiving a given amount from a specific age.

The amount is determined by the official minimum subsistence level and depends on partnership status but not on earnings or employment history. Statutory old-age pension provides Dutch residents with a pension benefit that in principle guarantees $70 \%$ of the minimum wage for a person living alone and $50 \%$ for each partner in a couple (married or living together).

If one spouse has reached the SRA and the other has not, the couple receives an extra allowance (the so-called partner allowance; 50 percent of the minimum wage) ${ }^{9}$ as long as the income of the younger spouse is not higher than the maximum allowance itself. Since August 2011, the amount of the partner allowance can be reduced by up to $10 \%$ if the joint monthly income is $€ 2,714$ gross or more. Table A2 in the appendix shows the AOW pension amounts by partnership status.

The partner allowance may therefore affect the retirement decision of younger spouses. Given that the presence of a spouse is likely to interfere with the effect of the individual's SRA receipt, we focus in this study on unmarried individuals only. The more complex case of retirement of a couple is left for future research.

\section{Second pillar: occupational pensions}

\footnotetext{
${ }^{7}$ The public old age pension system is regulated by the General Old Age Act 1957.

${ }^{8}$ See Table A1 in the appendix for the evolution of the SRA in the period under study.

${ }^{9}$ The partner allowance was introduced in 1985 and was discontinued on 1 April 2015 for new AOW pensioners.
} 
The second pillar, the occupational pension, is intended to help employees to maintain their accustomed standard of living after retirement. This is mandatory for most employees and for some independent professionals. This pillar is organized through pension funds at the level of a company or sector. In most arrangements, individuals can choose when they want to start receiving their annuity, with a minimum age before and a maximum age after the SRA. The amount is actuarially adjusted to the chosen starting age. Still, pension funds typically use a default in the communication with their participants, and this default often coincides with the SRA. The self-employed who are entitled to an occupational pension (usually because of an earlier job as an employee) may be affected by the default age. In our analysis, we will therefore consider the group of self-employed for whom this issue does not arise: we focus on the self-employed without any second pillar pension.

\section{Third pillar: private pensions}

The (third) private pension pillar is voluntary and offers some tax benefits for individuals who build up no or a limited occupational pension. This pillar is mainly relevant for the selfemployed and a small group of employees without occupational pensions; about one third of the self-employed participate in such a scheme. Most private pensions provide an annuity after a given age, independent of earnings from paid work or other income. This age can be chosen and postponed freely (within a wide range imposed by the tax rules) and is not linked to the SRA. We do not observe third pillar pensions in our data and can therefore not investigate whether individuals with such a pension respond differently to reaching the SRA.

\section{Taxes and social insurance}

In order to plausibly ascribe the effect of reaching the SRA to receiving AOW as of that age, we have to check whether there are other changes at SRA that may matter. For employees, access to unemployment and disability insurance changes at the SRA. This does not apply to the selfemployed, who have their own private insurance schemes (with low participation rates, due to the high costs). On the other hand, the self-employed are affected by the change in the income tax at SRA. AOW is largely financed out of the income tax paid in the first tax bracket, and since those who receive AOW are not supposed to also pay premium for it, individuals no longer pay the 
income tax meant for financing AOW after they have reached the SRA, irrespective of their paid work hours or earnings. This implies that the marginal tax rate in the first two tax brackets is much (17.9 \%-points) lower for individuals above than for individuals below SRA. This raises the reward for doing paid work after reaching the SRA and, if anything, should have a positive effect on doing paid work. It cannot explain the negative effect that we find.

\section{Data}

\section{Dataset}

Our empirical analysis is based on several datasets provided by Statistics Netherlands. We use a Dutch administrative dataset on personal incomes for all self-employed (PINKZELFST) and match this dataset with individual and household-level administrative data through anonymized identification codes. PINKZELFST is collected annually since 2007 and is available until 2015. It contains information on the self-employed population based on the income during an entire year reported in annual tax declarations (belastingaangiften). Apart from the information on incomes and deductions, PINKZELFST includes specific information on self-employment such as the type of self-employment, industry, and firm-size.

The definition of self-employed in this dataset is rather broad. Individuals are selfemployed if they work for their own account or risk in their own company (self-employed entrepreneur), as a director or main shareholder, in the company of a household member, or as an independent professional or freelance worker. Individuals remain in this dataset as long as they appear in the annual tax declaration with income or deductions from at least one type of selfemployment. ${ }^{10}$ In our study, following the literature and the OECD definition of self-employment, we will not consider directors or main shareholders.

In order to analyse the impact of reaching the SRA on the retirement decision, we first need to identify the exits from self-employment. We explicitly consider two destination states other than staying self-employed: retirement and employment. Table 1 shows the definitions of these labour market states. Other exits are considered as censored observations. Given that

\footnotetext{
${ }^{10}$ They may also receive income from other sources, such as wages as an employee.
} 
individual level labour-supply information is on an annual basis, we cannot identify the specific month in which the individual stops working but only the year of the transition.

\section{Table 1. Definition of labour market states}

\begin{tabular}{cl} 
Labour market States & Definition \\
\hline Self-employment & $\begin{array}{l}\text { The individual has income or deductions from any type of self-employment. The } \\
\text { individual may also be working in a paid job simultaneously. }\end{array}$ \\
Employment & $\begin{array}{l}\text { The individual has no income or deductions from self-employment but works in a paid } \\
\text { job (positive number of contributory days). }\end{array}$ \\
Retirement & $\begin{array}{l}\text { The individual has no income or deductions from self-employment or from a paid job, } \\
\text { has not died and has not exited to any social assistance (i.e., disability, unemployment } \\
\text { etc.) other than retirement pension. }\end{array}$
\end{tabular}

To construct the labour market states, we link PINKZELFST with other datasets using the anonymized individual identifier. To obtain employment status we use the employment dataset (BAANPRSJAARBEDRAGTAB), including information on paid work on a yearly basis. To identify retirement status we also consider the year of death $(D O)$ and the spells in which the individual is receiving other social assistance benefits (INTEGRAAL PERSOONLIJK INKOMEN).

In this study, we focus on the group of entrepreneurs, ${ }^{11}$ the largest group of selfemployed. However, for robustness we will also estimate the model for the broader and more heterogeneous group of self-employed (excluding directors). We add individual characteristics such as date of birth and gender, and information concerning individual and household incomes from other administrative datasets; the availability of all this information on the same individuals makes the data particularly useful for our objectives.

Table A3 in the appendix shows a detailed description of the variables included in the panel and the source of the information. The key independent variables represent the "treatment" (SRA) and financial wealth as a proxy for liquidity constraints. In the main specification, SRA takes value 1 from the moment the individual reaches the SRA. Interacting SRA with dummies for quintiles of financial wealth, we analyse how liquidity constraints affect the treatment effect of reaching the SRA. Moreover, we control for demographic and job characteristics. To avoid endogeneity problems and spurious correlation, we only include the initial values of these variables (usually

\footnotetext{
${ }^{11}$ Entrepreneurs are individuals whose main activity is managing their own business, with employees or not. The legal identity of the business is not separated from the owner's legal identity (unincorporated business). The legal form may be sole trader, general partnership or ordinary partnership.
} 
2007). Since retirement decisions may be affected by macroeconomic conditions, we also include the gender-specific regional unemployment rate.

\section{Sample}

In order to carry out the cleanest possible analysis of the LCM prediction, we select a sample of self-employed that rules out two factors affecting retirement that would possibly confound our results: joint retirement decisions and second pillar pensions.

Our sample consists of individuals who were entrepreneurs in 2008 and were born between 1943 and 1950. We select only those who were unmarried in January $2008 .^{12}$ We observe them until they leave self-employment or get married, or until the observation period ends (2015). In order to rule out other effects of reaching the SRA related to second pillar pensions or mandatory retirement of employees, we select only "pure entrepreneurs" without any occupational pension entitlement. ${ }^{13}$ The final sample consists of 15,341 entrepreneurs, ${ }^{14} 10,031$ males (65.4\%) and 5,310 females (34.6\%). This shows that self-employment is a male dominated mode of work, as in most countries (Hochguertel, 2010).

\subsection{Descriptive Statistics}

Table 2 shows some descriptive statistics by gender for our final sample in 2008. Most of the entrepreneurs have children, and this proportion is larger for women (77\%) than for men (58\%). Entrepreneurs in the sample are on average around 60 years old, with men slightly younger than women. Accordingly, around $8 \%$ of males and $9 \%$ of females already reached the SRA in 2008.

The data reveals a strong gender segregation by industry. Most of the entrepreneurs work in the services sector, especially women (89\%). $16 \%$ (7\%) of men (women) are in the agriculture sector and a smaller proportion of entrepreneurs works in construction ( $9 \%$ of men and only $0.8 \%$ of women). In line with the sample selection of "pure entrepreneurs", average tenure (as an entrepreneur in the same business) is high, 28 years. The dependency on self-employment income is captured by self-income, a dummy which is 1 if the main source of income is income from self-

\footnotetext{
12 Unmarried group includes single, divorce and widow status.

13 We consider pure entrepreneurs, those with no or a very small occupational pension (estimated yearly annuity lower than 1,500 euros). This information comes from Pensioenaanspraken.

${ }^{14}$ The selected dataset represents $7 \%$ of self-employed (excluding directors).
} 
employment. Most of the entrepreneurs ( $85.2 \%$ of men and $82.4 \%$ of women) have employees. Around $61 \%$ of unmarried entrepreneurs own the house where they live. The average gross household income and business wealth are similar for men and women.

Table 2. Descriptive statistics. Characteristics in 2008. Pure entrepreneurs. Unmarried men and women

\section{Children}

age_years

age_months

SRA

Regional unemployment rate self_income

Agriculture

Construction

Manufacturing

Services

Employees

Tenure

Home_ownership

In_GIH_n

Ln(business wealth normalized)

1.quintile of financial wealth

2.quintile of financial wealth

3.quintile of financial wealth

4.quintile of financial wealth

5.quintile of financial wealth

financial wealth net of debt

1.qfw net of debt

2.qfw net of debt

3.qfw net of debt

4.qfw net of debt

5.qfw net of debt

Observations

\begin{tabular}{|c|c|c|c|}
\hline \multicolumn{2}{|c|}{ Unmarried men } & \multicolumn{2}{|c|}{ Unmarried women } \\
\hline Mean & Std Dev. & Mean & Std Dev. \\
\hline $57.8 \%$ & 0.49 & $77.5 \%$ & 0.42 \\
\hline 60.56 & 2.22 & 60.70 & 2.28 \\
\hline 736.73 & 26.66 & 738.37 & 27.29 \\
\hline $7.6 \%$ & 0.26 & $8.8 \%$ & 0.28 \\
\hline 2.57 & 0.45 & 2.98 & 0.49 \\
\hline $87.02 \%$ & 0.35 & $72.8 \%$ & 0.45 \\
\hline $16.6 \%$ & 0.37 & $7.6 \%$ & 0.27 \\
\hline $9.7 \%$ & 0.30 & $0.8 \%$ & 0.09 \\
\hline $4.2 \%$ & 0.20 & $2.6 \%$ & 0.16 \\
\hline $69.4 \%$ & 0.46 & $89.0 \%$ & 0.31 \\
\hline $85.2 \%$ & 0.36 & $82.4 \%$ & 0.38 \\
\hline 28.41 & 15.31 & 28.35 & 16.31 \\
\hline $60.2 \%$ & 0.49 & $61.1 \%$ & 0.49 \\
\hline 13.86 & 0.05 & 13.86 & 0.05 \\
\hline 14.58 & 0.07 & 14.57 & 0.05 \\
\hline 402.5 & $3,558.6$ & $1,101.2$ & $3,184.53$ \\
\hline $7,950.6$ & $3,787.2$ & $10,375.5$ & $4,263.11$ \\
\hline $26,909.6$ & $7,616.9$ & $28,852.1$ & $7,521.04$ \\
\hline $83,857.0$ & $28,807.2$ & $83,626.3$ & $26,086.20$ \\
\hline $481,435.7$ & $517,200.9$ & $588,946.1$ & $2,274,496.75$ \\
\hline $90,161.7$ & $373,395.2$ & $108,151.1$ & $970,617.60$ \\
\hline$-64,157.1$ & $533,098.6$ & $-47,546.3$ & $160,524.83$ \\
\hline $4,357.6$ & $2,801.6$ & $6,686.5$ & $3,584.64$ \\
\hline $20,911.7$ & $6,170.8$ & $23,759.8$ & $5,967.21$ \\
\hline $71,372.7$ & $26,880.4$ & $72,346.0$ & $24,339.15$ \\
\hline $451,186.3$ & $491,490.6$ & $545,344.0$ & $2,229,164.83$ \\
\hline 10,031 & & 5,310 & \\
\hline
\end{tabular}

Note: Own elaboration. Source: Statistics in The Netherlands and Eurostat (for the regional unemployment rate).

Liquidity constraints are proxied by the quintile dummies of financial wealth at the start of 2008, gross or net of debt..$^{15}$ They are computed separately for men and women. The distribution of financial wealth shows the typical skewness with a small proportion of extremely rich people. The women in our sample are on average richer than the men.

\footnotetext{
${ }^{15}$ We use financial wealth net of debt in our benchmark model. Financial wealth contains total household financial assets (savings, bonds and shares), not including pension wealth (public or private). Financial wealth net of debt is equal to total household financial assets minus financial debts (excluding mortgage on the own house).
} 


\section{Self-employment exits}

Figure 1 shows the transition rates in our sample from self-employment into retirement for the years around the SRA, with age centered at SRA. The transition rates into retirement first increase with age. Against the prediction of the standard life cycle model, they show an unexpected jump starting two years before the SRA, probably due to the anticipation effect, and increasing more at the SRA. This applies both to men and women but the magnitude of the jump at the SRA is more pronounced for women (from $6.81 \%$ to $12.63 \%$ ) than for men (from $5.17 \%$ to 9.43\%). In the econometric model we will quantify the magnitude of this jump controlling for a rich set of covariates. The decline in the retirement rate at ages after the SRA may be explained by selection and the fall in the number of observations.

Figure 1. Transition rates from self-employment to retirement for unmarried men and women around the statutory retirement age. Percentage



Source: Own elaboration from CBS data. Age (in years) centred at the SRA.

\section{Profits}

One of the salient characteristics of the self-employed is the flexible work schedule. This may allow older entrepreneurs to adjust the hours of work to their preferences and retire gradually. We therefore want to see if besides the jump we observed in the retirement rates (the extensive margin) at the SRA, there is also a sharp decline in hours worked (the intensive margin). Unfortunately, information on hours worked is not available in our dataset, so we proxy it using 
(non negative) profits. ${ }^{16}$ Figure 2 shows the average profits by age and gender for the selfemployed individuals in our sample. ${ }^{17}$ Profits are generally higher for men than for women. They tend to fall smoothly with age, and do not show a sharp decline at age 65 . It therefore seems that older workers, given that they remain self-employed, gradually reduce their work intensity with age, without a clear discontinuity at the SRA.

Figure 2. Average (non-negative) profits (in real terms, 2015) by age. Unmarried males and females

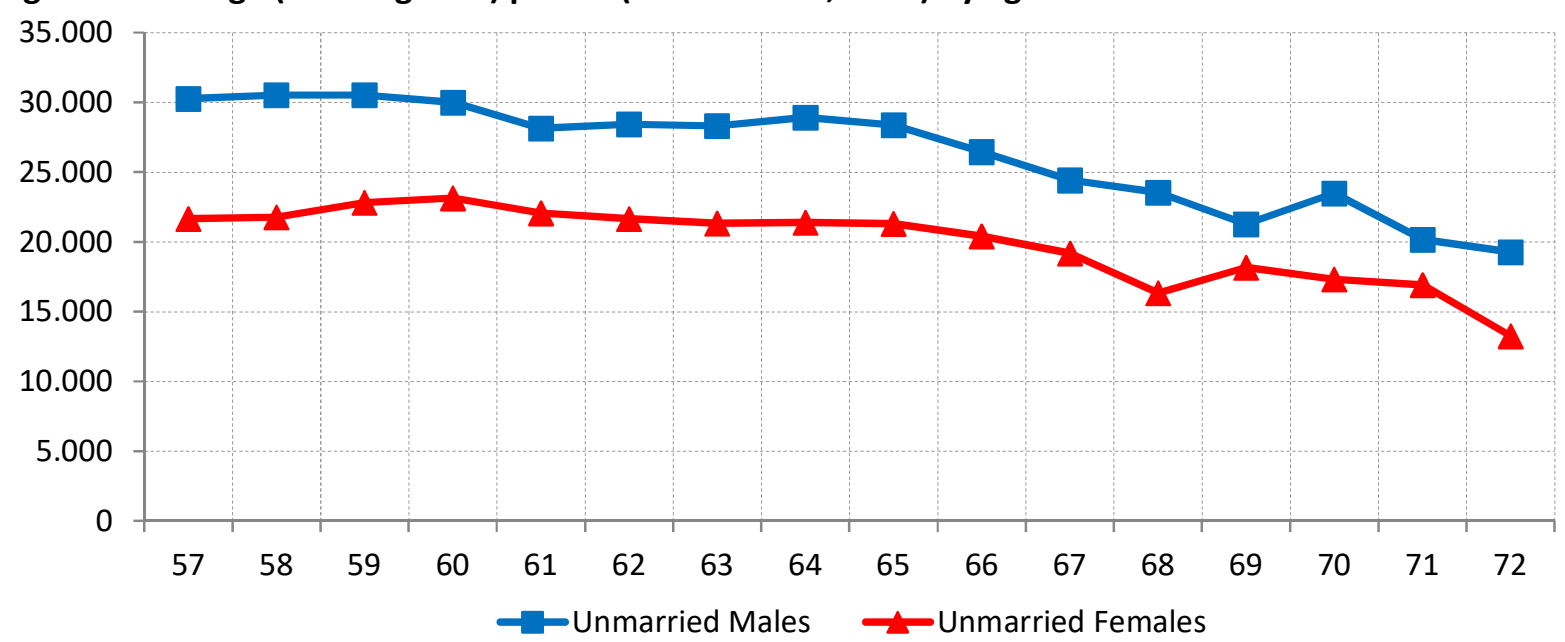

Source: Own elaboration from CBS data.

\section{Estimation strategy}

To estimate the causal impact of cash receipt (AOW) at the SRA on the retirement decision and profits of entrepreneurs, we use a sharp Regression Discontinuity design (RD). The identifying assumption is that, in the absence of receiving the old age pension (AOW) at the SRA, there should be no differences in transition rates just before and just after the SRA. The treatment is assessed by comparing those who are just below the age threshold (SRA) and those who have reached the SRA.

The fact that the assignment variable is age is crucial for identification, given that individuals cannot influence their age. However, individuals can retire earlier if they anticipate the future cash-in. This would imply a lower effect of AOW on the retirement decision at the SRA.

\footnotetext{
16 Profits are computed as turnover minus costs.

17 Observations with negative profits are discarded since they cannot be used as a proxy for work effort. Average profits include only the profits (non negative) of those who remain entrepreneurs.
} 
Moreover, as explained in Section 3, the change in the marginal income tax rate at the SRA might reduce the tendency to retire. Both would lead to an underestimation of the (positive) effect of the cash-receipt at SRA on the retirement hazard.

\subsection{Extensive margin: Transitions out of self-employment}

We model the transitions out of self-employment into wage employment or retirement using a discrete hazard model with a multinomial logit functional form. ${ }^{18}$ We assume that the propensities for person " $\mathrm{i}$ " to transit between time $\mathrm{t}$ and time $\mathrm{t}+1$ from self-employment to employment $(j=2)$ or retirement $(j=3)$ (with respect to the base outcome of staying in selfemployment, $\mathrm{j}=1$ ), are driven by the following index functions:

$$
\begin{gathered}
y_{i j}^{*}=\beta_{0 j}+\tau_{j} D_{i t}+\beta_{1 j} \cdot \operatorname{age}_{i t}+\beta_{2 j} \cdot a g e_{i t}^{2}+\sum_{k=3}^{6} \beta_{k j} \cdot\left(D_{i t} \times q_{f w_{i k t_{0}}}\right)+\beta_{7 j} u_{\text {rate } i t}+ \\
\beta_{8 j} \text { children }_{i t}+S_{i t}^{\prime} \delta_{j}+W_{i t_{0}}^{\prime} \vartheta_{j}+\varepsilon_{i j}
\end{gathered}
$$

Where $D_{i t}=1\left\{a g e_{i t} \geq S R A_{t}\right\}$ is the "treatment" dummy based on whether the individual has reached the SRA. Since the observed labour market status is on an annual basis (self-employed in year $t$ means having self-employment income in year $t$ ), SRA therefore enters in the model with a lag: If someone reaches the SRA in year $t$-1 and then retires immediately, there is no selfemployment income anymore in year $t$. Age (in months) is included in a quadratic form. We interact $D_{i t}$ with financial wealth quintile dummies to explore the role of liquidity constraints (using the quintiles of financial wealth at the beginning of the observation period $\left(q_{-} f w_{k}\right)$ to avoid endogeneity problems). We control for the state of the economy using the regional unemployment rate by gender (u_rate). We also control for children. The vector $S_{i t}$ contains selfemployment characteristics measured at time t: Industry and tenure of self-employment business. Finally, $W_{i t_{0}}^{\prime}$ is a vector of initial conditions, including the dummy employee that takes value 1 if the self-employed has at least one employee and 0 otherwise, wealth, and incomes, all measured at the beginning of the observation period. $\varepsilon_{i j}$ is an error term.

\footnotetext{
${ }^{18}$ Unfortunately, we cannot estimate duration models because we have no information on tenure.
} 
In a choice theoretical framework, $y_{i j}^{*}$ is seen as the indirect utility for person " $\mathrm{i}$ " associated with outcome $\mathrm{j}$. So, the individual will choose the option j if $y_{i j}^{*}>y_{i l}^{*} \forall l \neq j$. The error terms are assumed to be independently and identically distributed and to follow an extreme value distribution $P\left(\varepsilon_{i j} \leq z\right)=e^{-e^{-z}}$, independent of the regressors. ${ }^{19}$ The parameters for one of the choices, $j=1$, are normalized to zero.

The probability of the choice $y_{i j}=j$ given the regressors is.

$$
P\left(y_{i}=j \mid x_{i 1 \ldots} x_{i j}\right)=\frac{e^{x_{i j} \beta}}{\sum_{l=1}^{J} e^{x_{i l} \beta}}
$$

The model is estimated using maximum likelihood. The coefficients in the multinomial logit model have a similar interpretation as the coefficients in a binary logit model, treating one of the outcomes as the reference group. For instance, the relative risk of entering retirement rather than staying self-employed is: $\frac{\operatorname{Pr}\left(y_{i=3}\right)}{\operatorname{Pr}\left(y_{i=1}\right)}=e^{x_{i} \beta_{j}}$. Thus $e^{\beta_{3 r}}$ gives the proportional change in this relative risk when $x_{i r}$ changes by one unit.

Given that the model is non-linear, we compute the average marginal effects to measure the total effect of reaching the SRA on the retirement probability for different specifications.

\subsection{Intensive margin: profits}

Older workers may prefer gradual retirement, reducing their hours worked with age. Selfemployed individuals typically have more possibilities to do this than employees, since there are no employer-imposed restrictions. We therefore also want to analyse the impact of reaching the SRA on labour supply at the intensive margin. Given that there is no information on working hours, we use (the logarithm of) non-negative profits as a proxy. We do not address selection out of selfemployment or into negative profits; our analysis is conditional on remaining self-employed and having non-negative profits. We use a linear model for $\ln$ (profits +1$)(+1$ to make the dependent variable equal to 0 if profits are 0 ). The explanatory variables are the same as in equation (2) with the exception of the treatment dummy $D_{i t}=1\left\{a g e_{i t} \geq S R A_{t}\right\}$, entering the model without a lag and with different definitions (for details see section 6.2). We estimate this model by OLS.

\footnotetext{
${ }^{19}$ Since time variation in the data is limited we cannot estimate fixed effects models.
} 


\section{Estimation Results}

\subsection{Extensive margin: Transitions from self-employment to retirement}

We estimate three different specifications for the whole population and separately by gender. Complete estimation results are presented in Tables B1-B4 in the online appendix. Model 1 includes the treatment dummy of interest, SRA (one if the individual has reached the SRA, zero otherwise) and the controls. In Model 2, we decompose SRA into two dummies: SRAb captures the immediate response to reaching the SRA and SRAb $2^{20}$ captures the persistence of the effect in the years after reaching the SRA. Model 3 is similar to Model 1 but includes the interaction terms of the SRA dummy with dummies for financial wealth quintiles. ${ }^{21}$

To put the size of the estimated effects in perspective, it should be noted that (for Model 1), the average predicted probability of a transition from self-employment to retirement is $4.65 \%$ (5.27\% for women, $4.34 \%$ for men). The average predicted probability to remain working as selfemployed is $94.5 \%$. Since the probability to exit from self-employment to paid employment is small $(0.83 \%)$ and is not our primary interest, we focus our analysis on the retirement exit. First, we discuss the impact of the treatment (reaching the SRA).

\section{a. Effect of reaching the SRA on retirement \\ b.1. Global effect of reaching the SRA for all unmarried entrepreneurs}

Models 1 and 2 assume homogeneous effects, which can be seen as averages for the complete group of unmarried entrepreneurs. Table 3 presents the estimated average marginal effects (AME) and the coefficients. In Model 1, the positive and significant AME suggests that having reached the SRA increases the probability to go into retirement by 3.07 percentage points. In Model 2, we allow for lagged effects after reaching the SRA. The results show that reaching the SRA significantly increases the probability of retiring by 4 percentage points in the first year of cash-receipt. The impact dilutes over time to a 1.4 percentage point increase in the retirement probability one year later, showing that the short run effect is much larger than the effect in the longer run, in line with Figure 1.

\footnotetext{
${ }^{20} \mathrm{SRA} b$ is defined as 1 age $=\mathrm{SRA}$ \} and SRAb2 defined as 1 \{age $>\mathrm{SRA}$.

${ }^{21}$ In the benchmark model, financial wealth is net of debt.
} 
Table 3. Average Marginal Effects and Coefficients of the SRA on transitions into retirement for the population of unmarried (pure) entrepreneurs. Models 1 and 2

\begin{tabular}{lcccc} 
& \multicolumn{2}{c}{ Model 1 } & \multicolumn{2}{c}{ Model 2 } \\
\cline { 2 - 5 } 1.SRA_1 & Dydx & coeff. & dydx & coeff. \\
\cline { 2 - 5 } & $0.030794^{* * *}$ & $0.668949^{* * *}$ & & \\
\hline 1.SRAb_1 & $(0.003)$ & $(0.054)$ & & \\
& & $0.040813^{* * *}$ & $0.749448^{* * *}$ \\
1.SRAb2_1 & & $(0.004)$ & $(0.054)$ \\
& & $0.014409^{* * *}$ & $0.316761^{* * *}$ \\
& & $(0.004)$ & $(0.074)$ \\
\hline Observations & 87,320 & & 87,320
\end{tabular}

Notes: see Table B1 in the online appendix for complete estimation results of Models 1 and 2. Standard errors in parentheses. Average predicted probability for exit to retirement is 0.046466 using Model 1 and 2. AME are the average differences in the predicted probabilities between the given category and the reference with other variables at their observed values.

${ }^{*} p<0.05 ;{ }^{* *} p<0.01 ; * * * 0.001$

\section{b2. Global effects of reaching the SRA for unmarried entrepreneurs by gender}

Analogous to Table 3, Table 4 shows the effect of receiving the AOW allowance by gender using Models 1 and 2. The results for Model 1 suggest that women respond more strongly than men (3.7 versus 2.7 percentage points). This is in line with the typical finding that labour supply elasticities are lower for men than for women.

Table 4. Average Marginal Effects and coefficients of reaching the SRA on probability of transition into retirement for unmarried entrepreneurs by gender. Models 1 and 2

\begin{tabular}{|c|c|c|c|c|c|}
\hline \multirow{4}{*}{ Model 1} & \multirow{4}{*}{ 1.SRA_1 } & \multicolumn{2}{|c|}{ Men } & \multicolumn{2}{|c|}{ Women } \\
\hline & & dydx & coeff. & dydx & coeff. \\
\hline & & $0.027330 * * *$ & $0.656499 * * *$ & $0.037601^{* * *}$ & $0.695842^{* * *}$ \\
\hline & & $(0.003)$ & $(0.070)$ & $(0.005)$ & $(0.085)$ \\
\hline \multirow{4}{*}{ Model 2} & 1.SRAb_1 & $0.037153^{* * *}$ & $0.746405^{* * *}$ & $0.048237 * * *$ & $0.765604^{* * *}$ \\
\hline & & $(0.004)$ & $(0.070)$ & $(0.007)$ & $(0.085)$ \\
\hline & 1.SRAb2_1 & $0.011587^{* *}$ & $0.282272^{* *}$ & $0.019730 * *$ & $0.364584^{* *}$ \\
\hline & & $(0.004)$ & $(0.095)$ & $(0.007)$ & $(0.118)$ \\
\hline \multicolumn{2}{|c|}{ Observations } & 57,486 & & 29,834 & \\
\hline
\end{tabular}

Note: Estimated coefficients in Table B2 (Model 1) and Table B3 (Model 2) in the online appendix. Predicted probabilities of retirement using Model 1 are: Unmarried males: 0.0434; Unmarried females: 0.0527. Standard errors in parentheses. According to t-test, differences in AME between both samples are statistically significant in Model 1 at 90\% level of significance but differences are not statistically significant at $90 \%$ in Model $2 .{ }^{*} p<0.05 ;{ }^{* *} p<0.01 ;{ }^{* *} p<0.001$

In the years after becoming AOW eligible, the probability of retiring (SRAb2_1, Model2) remains higher than before eligibility, by 1.1 and 1.9 percentage points for men and women, respectively. This shows that oversensitivity to cash receipt still exists but the effect is lower than 
in the year of reaching the SRA (which, according to Model 2, is $3.7 \%$-points for men and 4.8\%points for women).

\section{b3. Marginal effects of reaching the SRA by financial wealth quintile}

Can liquidity constraints explain the sensitivity to cash-receipt found in Tables 3 and 4 ? Households with high financial wealth are unlikely to face liquidity constraints. Table 5 displays the marginal effects of reaching the SRA across quintiles of financial wealth (net of debt) for unmarried "pure entrepreneurs" separately by gender. Many of the differences between quintiles are significant (see Table B5 in the online appendix). Entrepreneurs' retirement probabilities increase when they reach the SRA across the financial wealth distribution, but there are differences in magnitude. The richest group does not face liquidity constraints and will often find the AOW-amount less important in terms of their total income.The reaction of the richest group therefore suggests that liquidity constraints alone cannot explain the peak observed at the SRA, so that the standard life cycle model with liquidity constraints is not sufficient for predicting retirement behaviour. Other possible explanations for the peak at the SRA are non-financial determinants of retirement (Van Erp, Vermeer and van Vuuren, 2014). Possibly the retirement decision is influenced by the social norm in society (e.g., discussed in the media), by the salient age accepted as the normal age of retirement, or by the behaviour of someone's peers (since the SRA is the age of mandatory retirement for almost all employees). These explanations cannot be disentangled here, due to the uniform nature of the AOW eligibility.

The pattern is non-monotonic. Entrepreneurs in the $2^{\text {nd }}$ and $4^{\text {th }}$ quintile show the highest increase in the retirement probability at the SRA. The strong response of those in the $2^{\text {nd }}$ quintile might be driven by liquidity constraints, but it is not clear then why this does not apply to the first wealth quintile, which shows a rather low treatment effect. In line with the previous results (Table 4), women tend to react more than men but the difference decreases with financial wealth, becoming negligible for the richest group. The stronger reaction of women may be due to their higher sensitivity to the social norms or age anchors, in line with Vermeer (2016) who finds that the age anchor implied by the statutory retirement age influences the expected retirement age of women but not of men. 
Table 5. Average Marginal Effects (AME) of reaching the SRA on the transition from selfemployment to retirement over quintiles of financial wealth by gender. Model 3

\begin{tabular}{cccc} 
& All & Men & Women \\
\cline { 2 - 4 } 1.qfwe_net_debt & $0.025545^{* * *}$ & $0.022227^{* * *}$ & $0.032415^{* * *}$ \\
& $(0.004)$ & $(0.005)$ & $(0.008)$ \\
2.qfwe_net_debt & $0.040569^{* * *}$ & $0.033578^{* * *}$ & $0.052304^{* * *}$ \\
& $(0.004)$ & $(0.005)$ & $(0.007)$ \\
3.qfwe_net_debt & $0.029858^{* * *}$ & $0.026815^{* * *}$ & $0.036076^{* * *}$ \\
& $(0.004)$ & $(0.004)$ & $(0.007)$ \\
4.qfwe_net_debt & $0.037455^{* * *}$ & $0.035271^{* * *}$ & $0.041848^{* * *}$ \\
& $(0.004)$ & $(0.005)$ & $(0.008)$ \\
5.qfwe_net_debt & $0.018795^{* * *}$ & $0.018253^{* * *}$ & $0.019362^{*}$ \\
& $(0.005)$ & $(0.005)$ & $(0.009)$ \\
\hline Observations & $\mathbf{8 7 , 3 2 0}$ & $\mathbf{5 7 , 4 8 6}$ & $\mathbf{2 9 , 8 3 4}$ \\
\hline
\end{tabular}

Note: Estimated coefficients of Model 3 in table B4 in the online appendix. Standard errors in parenthesis. ${ }^{*} p<0.05 ;{ }^{* *} p<0.01 ; * * *$ $p<0.001$

\section{b. Coefficients on the covariates}

As expected, individuals living in regions with higher unemployment rates have a higher probability of retirement. The estimated coefficient is larger for women than for men, suggesting that women are more sensitive to regional labour market conditions. Having children has a positive but insignificant effect on retirement for both genders. For most of the age range, age has a positive effect on retirement (until age 67 or 68 ), reflecting the increase of the marginal utility of leisure with age. This effect is stronger for women than for men.

Other things being equal, the richest (in terms of financial wealth) men and women show the highest probability of retirement. Among the rest of the wealth distribution there are no significant differences in the retirement probability except that women in the second quintile are less likely to retire than those in the reference category (first quintile). Homeownership has no effect on the retirement probability for women but reduces it slightly for men. Gross household income is positively but insignificantly associated with the retirement probability. In contrast, business wealth (which can be seen as a proxy for business success) is negatively associated with the transition to retirement.

Entrepreneurs working in manufacturing are less likely to retire than those working in other sectors. Having self-employment income as the main source of income and having employees reduce the probability of retirement. In contrast, unexpectedly, tenure (as an entrepreneur in the same business) increases this probability. 


\subsection{Intensive margin: Profits}

It may be that those self-employed who work longer reduce their hours of work when ageing given the flexibility of self-employment and the increase of preferences for leisure with age. Our main interest is to figure out if there is a discontinuous change in profits (as a proxy for working hours) specifically once the entrepreneur become entitled for the old age pension. We estimate an equation for log profits for the whole population of unmarried pure entrepreneurs with non-negative profits and separately for unmarried males and females. Model 1 includes the treatment dummy of interest, SRAb2 (one for the years after reaching the SRA, zero otherwise) and the controls. In Model 2, we decompose SRA into three dummies: SRAC captures the response to reaching the SRA in the year of reaching the SRA (incomplete effect, if SRA is reached later in the year); SRAC1 captures the response in the year after reaching the SRA (the complete "short run" effect); and SRAC2 captures the long-run effects in the later years. ${ }^{22}$ Model 3 is similar to Model 1 but includes the interaction terms of the SRA dummy with dummies for financial wealth quartiles. $^{23}$ The other explanatory variables in all three models are the same as those in Section 6.1 .

\section{a. Effect of reaching the SRA on profits}

\section{b.1. Global effect of reaching the SRA on profits}

Table 7 shows the coefficient of SRA on log non-negative profits for Models 1 and 2 using OLS for unmarried pure entrepreneurs. In Model 1, the coefficient of the dummy SRAb2 is negative and significantly different to zero, suggesting that entrepreneurs reduce their working hours after reaching the SRA. The coefficients in Model 2 suggest that the decline in profits does not take place in the specific year in which entrepreneurs start cashing-in their old age pension (mostly incomplete amount), but gradually increases in magnitude in the following years, revealing gradual retirement behaviour and larger long-run than short-run effects.

\footnotetext{
22 SRAC is defined as 1 age= $=$ SRA\}; SRAC 1 is defined as 1 age=SRA +1 \} and SRAC2 is defined as 1 age $>\mathrm{SRA}+1\}$.

${ }^{23}$ In the benchmark model, financial wealth is net of debt. The model of profits fits better when we include financial wealth in quartiles instead of in quintiles.
} 
Table 7. Marginal effects (coefficients) of reaching the SRA on In(non-negative profits+1) for unmarried entrepreneurs. OLS. Model 1 and Model 2

\begin{tabular}{lcc} 
& Model 1 & Model 2 \\
\cline { 2 - 3 } SRAb2 & $-0.102831^{* * *}$ & \\
& $(0.019302)$ & \\
\hline SRAC & -0.022164 \\
& $(0.015009)$ \\
SRAC1 & $-0.076602^{* * *}$ \\
& $(0.021556)$ \\
SRAC2 & $-0.211596^{* * *}$ \\
& $(0.028357)$ \\
\hline Observations & 68,311 & 68,311 \\
\hline Note: Standard errors in parenthesis. See Table B6 in the online Appendix. ${ }^{*} p<0.05 ; * * 0<01 ; * * * 0.001$
\end{tabular}

b2. Effect of reaching the SRA on profits by gender

Analogous to Table 7, Table 8 shows the coefficients of reaching the SRA on profits separately by gender. According to Model 1 , the coefficient of the dummy SRAb2 is significantly negative at $0.1 \%(1 \%)$ level for men (women). The size of the effect is very similar for men and women: Profits decline by $10 \%$ after reaching the SRA. This implies a reduction in annual profits of $1,132(1,606)$ euros for a female (male) individual at the median of non-negative profits. Again, the estimates of Model 2 suggest that the decline in profits does not happen in the year of reaching the SRA, but in the following years. In the year immediately following the SRA (SRAC1), women are slightly more responsive than men. The later effect (SRAC2) is the largest (around 20\%) and the most significant effect for both genders.

Table 8. Marginal effects of reaching the SRA on In(non-negative profits+1) for unmarried men and women OLS. Model 1 and Model 2

\begin{tabular}{|c|c|c|}
\hline \multirow{3}{*}{ SRAb2 } & Men & Women \\
\hline & \multicolumn{2}{|c|}{ Model 1} \\
\hline & $-0.099368 * * *$ & $-0.101330 * *$ \\
\hline & $(0.023500)$ & $(0.033663)$ \\
\hline & \multicolumn{2}{|c|}{ Model 2} \\
\hline \multirow[t]{2}{*}{ SRAC } & -0.014346 & -0.035374 \\
\hline & (0.018132) & (0.026553) \\
\hline \multirow[t]{2}{*}{ SRAC1 } & $-0.067456 * *$ & $-0.086080 *$ \\
\hline & (0.026145) & (0.037861) \\
\hline \multirow[t]{2}{*}{ SRAC2 } & $-0.211422 * * *$ & $-0.203176 * * *$ \\
\hline & $(0.034517)$ & $(0.049534)$ \\
\hline Obser & 44,957 & 23,354 \\
\hline
\end{tabular}

Note: Standard errors in parenthesis. See Table B6 in the online appendix. ${ }^{*} p<0.05 ;{ }^{* *} p<0.01 ;{ }^{* * *} p<0.001$ 
In terms of hours worked, these results suggest that entrepreneurs respond to reaching the SRA by gradually reducing their work intensity from the year after reaching the SRA ownwards, revealing gradual retirement behaviour of both genders.

\section{b3. Effects of reaching the SRA on profits by financial wealth quintile}

In order to test if credit constraints explain why entrepreneurs' profits fall at the SRA as found in table 8, we add interactions of the wealth quartile dummies with the SRA dummy (SRAb2) in Model 1. Table 9 shows the marginal effects of reaching the SRA on log non-negative profits by quartiles of financial wealth.

Table 9. Marginal effects of reaching the SRA on $\ln ($ non-negative profits+1) by financial wealth quartiles for unmarried men and women. OLS. Model 3

\begin{tabular}{lcc} 
& Men & Women \\
\cline { 2 - 3 } 1.quartile_fwt & $-0.098853^{* *}$ & $-0.134964^{* *}$ \\
& $(0.033421)$ & $(0.047521)$ \\
2.quartile_fw & $-0.190167^{* * *}$ & -0.048842 \\
& $(0.033155)$ & $(0.044736)$ \\
3.quartile_fw & -0.059474 & $-0.190649 * *$ \\
& $(0.032769)$ & $(0.048662)$ \\
4.quartile_fw & -0.050388 & -0.040704 \\
& $(0.033056)$ & $(0.049816)$ \\
\hline Note: Standard errors in parenthesis. See Table $B 7$ in the online appendix. ${ }^{*} p<0.05 ; * * 0<0.01 ; * * 0<0.001$
\end{tabular}

The effects of reaching the SRA on profits across the wealth distribution vary by gender. Male entrepreneurs' profits fall significantly at the SRA for those in the first and second quartile of the wealth distribution and insignificantly for those in the third and fourth quartiles. Profits decline significantly by $10 \%$ and $19 \%$ in the first and second quartile, respectively, but much less (6\% and $5 \%)$ for the other quartiles.

Women's profits exhibit a non-monotonic pattern, showing a significant decline in profits at the SRA only in the $1^{\text {st }}$ and $3^{\text {rd }}$ quartile, where the effect is significant at $-13 \%$ and $-19 \%$, respectively. We do not have a good explanation why the effect is particularly strong in the $3^{\text {rd }}$ quartile. It seems that for men, only those who face liquidity constraints show a significant decline in work intensity after reaching the SRA. This fits with the prediction of the standard lifecycle model with liquidity constraints. The non-monotonic pattern of women cannot be completely 
explained by the standard life cycle model with liquidity constraints. The distinct response to reaching the SRA across the wealth distribution by sex might be because women are more responsive to social norms and peer effects. That would be in line with Vermeer(2016) discussed above, and with de Grip, Fouarge and Montizaan (2013), who find that the expected retirement age of women is more sensitive to age anchors than that of men.

\section{b. Coefficients on the covariates}

Complete estimation results in online appendix tables B6 and B7 show that most covariates affect profits of men and women in the same direction. Profits increase significantly with age until reaching the maximum at age 60 . Having children increases profits mainly for men (19\%). Surprisingly, before reaching the SRA, women in the fourth quartile of financial wealth earn lower profits than women in other quartiles. As expected, entrepreneurs whose main source of income is self-employment earn higher profits. Homeowners also earn more money than nonhomeowners. Gross income household and business wealth are positively associated with profits. Tenure has a positive and small effect on females' profits but not on males' profits.

Agriculture (the reference category) is the industry where the highest profits are earned, followed by services (where earnings are 18\% (9\%) lower than in agriculture for men (women)), construction and manufacturing.

\subsection{Sensitivity analysis}

In this section we, first, provide some robustness checks to test whether the effects of reaching the SRA on retirement and earnings are not sensitive to the definitions of "pure entrepreneur" or financial wealth. Secondly, we check whether the effects found are sensitive to the sample of entrepreneurs selected.

\section{a) Sensitivity to the definition of "pure entrepreneur" or financial wealth}

We estimate several models for four specifications, using financial wealth gross and net of debt as a proxy of liquidity constraints and defining pure entrepreneurs based on the lack of 
occupational pension or past employment history. ${ }^{24}$ Recall that in our benchmark specification (second column in tables of robustness checks), financial wealth is net of debt and pure entrepreneurs are not (or hardly) entitled to an occupational pension.

First, global marginal effects of transitions from self-employment to retirement are similar in all the estimations in Table B8 (in the online appendix), confirming the robustness of the peak found at the SRA for men and women. Second, Table B9 (in the online appendix) shows the robustness of the peak in retirement at the SRA across the wealth distribution. We observe qualitatively similar results for men in the four specifications (Figure 3). Women exhibit small differences in the magnitude of the peak across the wealth distribution between specifications using financial wealth net of debt and gross of debt (Figure 4). The latter specification shows a decreasing magnitude of the SRA effect with wealth except for the $1^{\text {st }}$ quintile. These differences are small and insignificant.

Figure 3. Average Marginal Effects of the SRA on retirement by financial wealth quintile; men

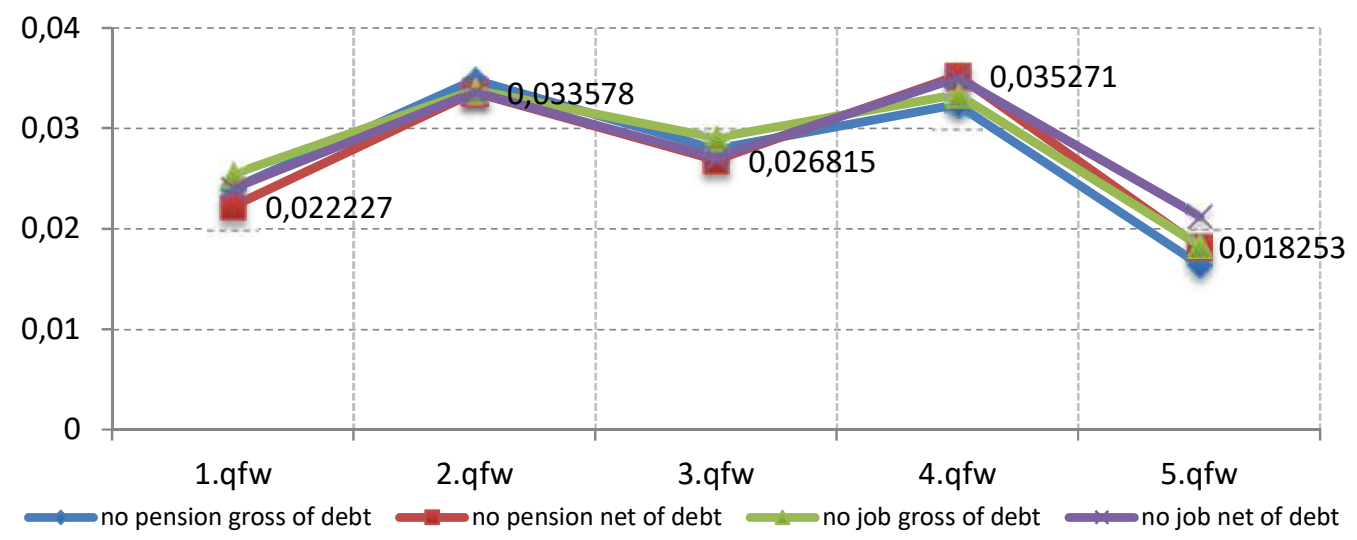

Note: See table B9 (top) in the online appendix.

Analogous to Table B8, Table B10 (in the online appendix) shows the marginal effect of reaching the SRA on profits using OLS estimation. Results are qualitatively similar in most specifications. They show smaller and less significant coefficients in the specifications using the definition of pure entrepreneur based on lack of past wage employment.

\footnotetext{
${ }^{24}$ According to the alternative definition, "pure entrepreneurs" are those entrepreneurs without any spell of past wage employment (since 1996).
} 
Figure 4. Average Marginal Effects of the SRA on retirement by financial wealth quintile; women



Note: See table B9 (bottom) in the online appendix.

Table B11 (in the online appendix) displays the marginal effect of reaching the SRA on profits by financial wealth quartiles. Most of the results are qualitatively similar to the benchmark model. Women's estimates confirm the sharp decline in profits at the SRA for those in the $3^{\text {rd }}$ quartile and the insignificant decline for those in the top of the wealth distribution. Only in our benchmark model, those in the first quartile exhibit a significant decline in profits at the SRA. For men, all estimates confirm the largest decline in profits at the SRA in the $2^{\text {nd }}$ quartile and, with the exception of specification (4), the lowest decline for the richest group. In specification (4), ${ }^{25}$ those in the top quartile of the wealth distribution show a significant decline in profits.

\section{b) Sensitivity to the sample of entrepreneurs in transitions out of self-employment}

We estimate Models 1 and 3 for the benchmark specification ${ }^{26}$ for the sample of unmarried pure self-employed (excluding directors or main shareholders). Table B12 (in the online appendix) shows the average marginal effect of reaching the SRA on the transition from selfemployment to retirement. Similar to what we observed for entrepreneurs, global marginal effects are positive and significant for both sexes and are larger for women. The magnitude of the

\footnotetext{
${ }^{25}$ In the specification (4), pure entrepreneurs are those without past employment spells and financial constraints are proxied by financial wealth net of debt.

${ }^{26}$ For self-employed we can not control by business wealth, tenure or number of employees. We include a dummy entrepreneur that takes value 1 if the individual is entrepreneur.
} 
effect compared to that found for entrepreneurs is similar for men and larger for women, probably driven by the stronger reaction of freelance women.

Figure 5 and Table B13 (in the online appendix) show the oversensitivity to reaching the SRA across the wealth distribution by gender. The pattern for women is qualitatively similar to our benchmark model of entrepreneurs. The pattern for men shows small differences in the first and third quantile, they exhibit a higher over-reaction than in our benchmark model.

Figure 5 Average Marginal Effect of the SRA on retirement by financial wealth and by gender.

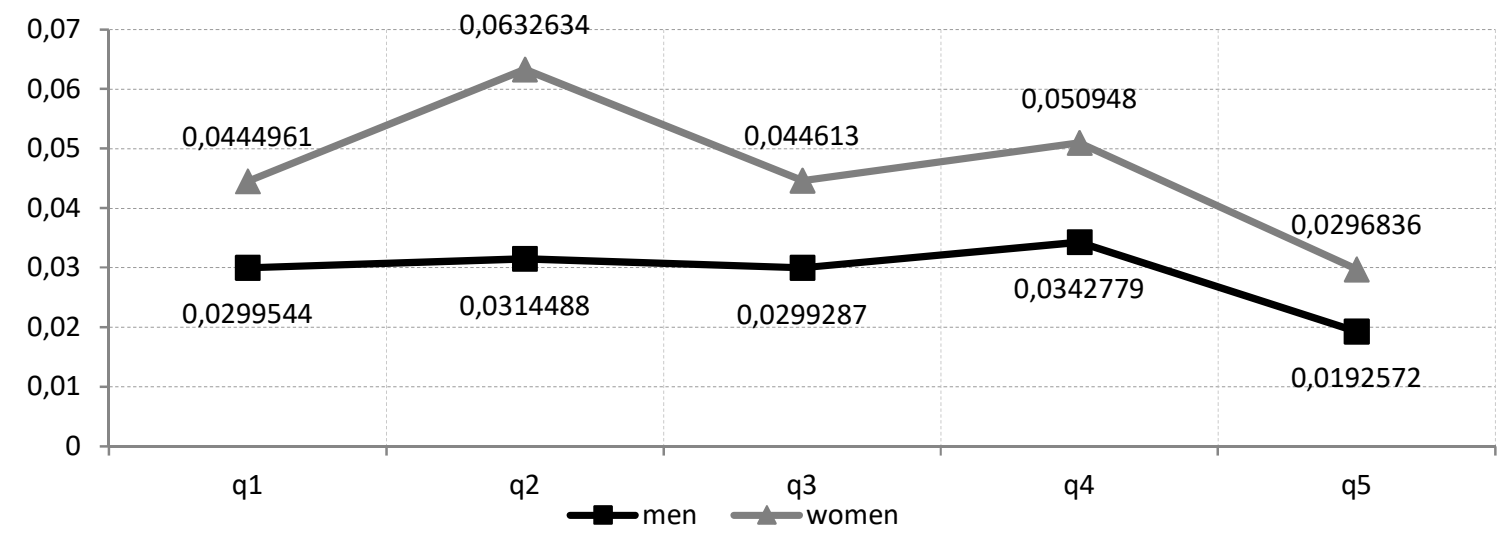

Note: see table $B 13$

\section{Conclusions}

In this study we have analysed the labour supply response of the self-employed to reaching the statutory retirement age (SRA; 65 years) both at the extensive (retirement decision) and intensive margin (hours worked) in the Netherlands. After the SRA, each Dutch resident receives the Old Age State Pension (AOW), a fixed income at the subsistence level. Making use of the anticipated AOW cash-receipt and the supply side decision of entrepreneurs, we test the implication of the standard life cycle model that an anticipated income change does not lead to any reaction in labour supply. Accordingly, rational retirement or labour supply behaviour should not exhibit any discontinuous changes at the time of reaching the SRA, particularly if workers are not liquidity constrained. Any over sensitivity to cash receipt could be explained by: i) liquidity constraints or ii) behavioural determinants, such as social norms, peer effects, or age anchoring. 
Using a rich administrative Dutch dataset, we estimated the average treatment effect of reaching the SRA on the retirement probability out of self-employment (the extensive margin) and on profits (as a proxy for labour supply at the intensive margin). We also explored if treatment effects vary by gender or wealth level.

Focusing on the extensive margin, our findings clearly point at over sensitivity to reaching the entitlement age for the state pension, where on average for all entrepreneurs, the transition probability to retirement increases by 3 percentage points. The effect on the transition rate is much larger in the short run than in the longer run.

Entrepreneurs' retirement probability increases when they reach the SRA across the financial wealth distribution, but there are differences in magnitude, with an inversely U-shaped pattern for both genders. The over-reaction of the richest group suggests that liquidity constraints cannot explain the peak observed at the SRA, so that the standard life cycle model with liquidity constraints is not sufficient for predicting retirement behaviour. Considering differences by gender, we find that the response of reaching the SRA on labour supply is larger for women than for men. This gender difference falls with financial wealth and disappear for the wealthiest group.

Lastly, results on the impact of reaching the SRA at the intensive margin (using profits as a proxy for work effort) reveal that men and women reduce work effort gradually from the year after reaching the SRA onwards. In particular, men in the lowest wealth groups who are most likely to face liquidity constraints have declining profits, in line with the prediction of the life cycle model with liquidity constraints. For women, however, the strong decline in profits in the $3^{\text {rd }}$ wealth quartile requires other (behavioural) explanatios. The gender differences at the extensive and intensive margin may be due to a larger influence of social norms and peer effects on women than on men that has been found in the literature.

This study helps to understand the retirement behaviour of older workers without employer's restrictions, a policy relevant issue in the ageing society. Our results fit with the recommendations on how to keep people in the labour market longer. If people are strongly affected by the social norms, age anchors and peer effects, optimal policies to encourage workers to work longer should include changes in social norms and age anchors, as also suggested by Kautonen, Tornikoski and Kliber (2011). If people are affected by the age anchor of the SRA, an 
increase in the SRA may also have an indirect effect extending work careers. In addition, policies can go in the direction of communication campaigns increasing the positive awareness of older workers' participation in the labour market.

In many countries, the self-employed are seen as a vulnerable group in terms of pension adequacy, including the Netherlands. They typically have a low mandatory occupational pension and are supposed to accumulate their own pension savings, in the form of voluntary pension products or the value of their company that can be sold and transformed into a source of pension income after retirement. The additional freedom they have is useful if they make optimal decisions. Our findings of over sensitivity to cash receipt suggest, however, that their decisions are not optimal but subject to behavioural biases. If this applies to their retirement behaviour, it may also apply to the more complicated long-term decisions of saving for retirement. This suggests policies focused on choice architecture or tax nudges ${ }^{27}$ that might help to alleviate this concern and reduce the vulnerability of the self-employed from the perspective of pension adequacy.

This study has the limitation that the non-financial determinants of retirement (e.g peer effects, social norms, age anchor, reference point) are not disentangled. As a consequence, we cannot distinguish which of these factors contribute to explaining the over-sensitivity to cashreceipt at the SRA or the differences in this by gender and wealth level. A more structural analysis, requiring additional data that are typically not available in administrative sources, may help to analyse this further. A deeper knowledge of the behavioural determinants will be useful to design appropriate policies influencing retirement behaviour.

${ }^{27}$ Selin (2012) finds that pension deductions play an important role for promoting pension savings among self-employed in Sweden. 


\section{References}

Atalay K., and Barrett, G. F. (2016). Pension Incentives and the Retirement Decisions of Couples. IZA Discussion paper 10013, IZA, Bonn.

Behaghel, L. and Blau, D. (2012). Framing Social Security Reform: Behavioral Responses to Changes in the Full Retirement Age. American Economic Journal: Economic Policy, 4(4), 41-67.

Borella, M., Coda Moscarola, F., and Rossi, M. (2014). (Un)expected Retirement and the Consumption Puzzle. Empirical Economics, 47(2), 733-751.

Borella, M., Fornero, E., and Rossi, M. (2009). Does Consumption Respond to Predicted Increases in Cash-hand Availability?. Evidence from the Italian "Severance Pay." Economics Letters, 105(1), 127-129.

Brown, J. R., Coile, C. C., and Weisbenner, S. J. (2010). The Effect of Inheritance Receipt on Retirement. Review of Economics and Statistics, 92(2), 425-434.

Caliendo, M., Fossen, F., and Kritikos A. (2014). Personality Characteristics and Decisions to Become and Stay Self-employed. Small Business Economics, 42(4), 787-814.

Deaton, A. (1992). Understanding Consumption. Oxford University Press, Oxford.

Georgellis Y., Sessions, J., and Tsitsianis N. (2005). Windfalls, Wealth, and the Transitions to SelfEmployment. Small Business Economics, 25(5), 407-428.

Grip, A. de, Fouarge, D., and Montizaan, R. (2013). How Sensitive are Individual Retirement Expectations to Raising the Retirement Age. De Economist, 161(3), 225-251.

Guariglia, A., and Rossi, M. (2002). Consumption, Habit Formation and Precautionary Saving: Evidence From the British Household Panel Survey. Oxford Economic Papers, 54(1), 1-19.

Heim, B. (2015) Understanding the Decline in Self-employment among Individuals Nearing Retirement. Small Business Economics, 45(3), 561-580.

Hochguertel, S. (2010). Self-Employment around Retirement Age. In Entrepreneurship, SelfEmployment and Retirement, Sappleton, N. and Lourenço F. (eds.), Palgrave McMillan, New York, pp. 209-258.

Hurd, M. (1990). No Research on the Elderly: Economic Status, Retirement, and Consumption and Saving. Journal of Economic Literature, 28(2), 565-637.

Johanson, E. (2000). Self-employment and Liquidity Constraints: Evidence from Finland. 
Scandinavian Journal of Economics, 102(1), 123-134.

Kautonen, T., Tornikoski E. and Kliber E. (2011). Entrepreneurial Intentions in the Third Age: the Impact of Perceived Age Norms. Small Business Economics, 37(2), 219-234.

Minola, T., Criaco, G., and Obschonka, M. (2016). Age, Culture, and Self-employment Motivation. Small Business Economics, 46(2), 187-213.

Nykvist J. (2008) Entrepreneurship and Liquidity Constraints: Evidence from Sweden. Scandinavian Journal of Economics, 110(1), 23-43.

Parker, S.C., and Rougier, J.C. (2007). The Retirement Behaviour of the Self-employed in Britain. Applied Economics, 39(6), 697-713.

Peri, G., Romiti, A., and Rossi, M. (2015). Immigrants, Domestic Labor and Women's Retirement Decisions. Labour Economics, 36, 18-34.

Picchio, M., Suetens, S., and van Ours, J. C. (2017). Labour Supply Effects of Winning a Lottery. The Economic Journal, forthcoming. http://doi.org/10.1111/ijlh.12426

Rossi, M., and Trucchi, S. (2016). Liquidity Constraints and Labor Supply. European Economic Review, 87(1), 146-193.

Schuetze, H. J. (2015). Self-Employment and Retirement in Canada : The Labour Force Dynamics of Older Workers. Canadian Public Policy, 41(1), 65-85.

Seibold, A. (2017) Reference Dependence in Retirement Behavior: Evidence from German Pension Discontinuities. mimeo, London School of Economics.

Selin, H. (2012). Marginal Tax Rates and Tax-Favoured Pension Savings of the Self-employed: Evidence from Sweden. Scandinavian Journal of Economics, 114(1),79-100.

Van Erp, F., Vermeer, N., and van Vuuren, D. (2014). Non-financial Determinants of Retirement : A Literature Review, De Economist, 162(2), 167-191.

Vermeer, N. (2016). Age Anchors and the Expected Retirement Age: An Experimental Study. De Economist, 164(3), 255-279.

Zissimopoulos, J. M., and Karoly, L. A. (2007). Transitions to Self-employment at Older Ages: The Role of Wealth, Health, Health Insurance and other Factors. Labour Economics, 14(2), 269295. 


\section{Appendix}

Table A1 Evolution of the Statutory Retirement age 2008-2015

\begin{tabular}{lll} 
Year & Retirement Age & Birthdate \\
\hline $2008-2012$ & 65 & 1 January Year-65 \\
2013 & $65+1$ month & 1 January 1948 to 30 November 1948 \\
2014 & $65+2$ months & 1 December 1948 to 31 October 1949 \\
2015 & $65+3$ months & 1 November 1949 to 30 September 1950
\end{tabular}

Source: Statistics Netherlands

Table A2 AOW pension amount by partnership status. As of July 2016

\begin{tabular}{|c|c|c|c|c|c|}
\hline & \multirow[b]{3}{*}{ Single } & \multicolumn{4}{|c|}{ Household amount for couples } \\
\hline & & \multirow[b]{2}{*}{$\begin{array}{l}\text { Both receiving } \\
\text { an AOW } \\
\text { pension }\end{array}$} & \multicolumn{3}{|c|}{ No partner's AOW } \\
\hline & & & $\begin{array}{l}\text { No supplementary } \\
\text { allowance }\end{array}$ & $\begin{array}{l}\text { Supplementary } \\
\text { allowance }\end{array}$ & $\begin{array}{l}\text { Reduced } \\
\text { supplementary } \\
\text { allowance }\left({ }^{*}\right)\end{array}$ \\
\hline Gross (not holiday allowance) & $1,153.35$ & $1,589.18$ & 794.59 & $1,563.62$ & $1,486.72$ \\
\hline $\begin{array}{l}\text { Tax and insurance } \\
\text { contributions }\end{array}$ & 214.83 & 295.34 & 147.67 & 291.17 & 276.92 \\
\hline Zvw contribution (5.4\%) & 62.28 & 85.80 & 42.9 & 84.43 & 80.28 \\
\hline Net & 876.24 & $1,208.04$ & 604.02 & $1,188.02$ & $1,129.52$ \\
\hline
\end{tabular}

Source: The Sociale Verzekeringsbank.

Note: These amounts are the full AOW pension amounts which apply when the individual has built up AOW pension rights for the maximum period of 50 years. These amounts correspond to individuals without tax credit.

The gross amount includes the AOW top-up of $€ 25.56$. The gross amount excludes the holiday allowance.

* Since 1 August 2011, the supplementary allowance can be reduced by up to 10\%. This reduction applies to households with a joint monthly income of $€ 2,714.68$ gross or more. 
Table A3 Definition of explanatory variables

Variable

\begin{tabular}{|c|c|c|}
\hline \multicolumn{3}{|c|}{ Personal characteristics } \\
\hline Married & $\begin{array}{l}1 \text { if self-employed is married or in a partnership at } 1 \text { st } \\
\text { January of each year }\end{array}$ & GBABURGERLIJKESTAATBUS \\
\hline Children & 1 if the individual has children & KINDOUDERTAB \\
\hline Age_months & $\begin{array}{l}\text { Age (in months) of the self-employed, computed 1st } \\
\text { January of each year. Age within the model has as a } \\
\text { quadratic form }\end{array}$ & GBA PERSOONTAB \\
\hline Statutory retirement age (SRA) & $\begin{array}{l}1 \text { from the year the self-employed reaches the statutory } \\
\text { retirement age and start receiving AOW. This variable is } \\
\text { included with a lag in the estimations }\end{array}$ & GBA PERSOONTAB \\
\hline \multicolumn{3}{|c|}{ Self-employment characteristics } \\
\hline Industry & $\begin{array}{l}\text { Dummies for manufacturing, construction, services and } \\
\text { agriculture }\end{array}$ & PINKZELFST \\
\hline Tenure & $\begin{array}{l}\text { Time (in years) since the inscription of the company in the } \\
\text { Chamber of commerce. Proxy for seniority as entrepreneur } \\
\text { in the same business. We take the most recent informed, } \\
\text { censored to starting age of } 16\end{array}$ & PINKZELFST \\
\hline
\end{tabular}

Macroeconomic variables (to capture the business cycle)

\begin{tabular}{|c|c|c|}
\hline $\begin{array}{l}\text { Regional unemployment rate by } \\
\text { gender }\end{array}$ & $\begin{array}{l}\text { Yearly regional (at province level, Nuts2) unemployment } \\
\text { rate by gender. (For the regional unemployment rate, see } \\
\text { http://ec.europa.eu/eurostat/data/database?node code=t } \\
\underline{\text { gs00010 }} \\
\text { Initial conditions }\end{array}$ & GBAADRESBUS and Eurostat \\
\hline $\begin{array}{l}\text { Quantiles of net financial wealth } \\
\text { (qfwe_debt) }\end{array}$ & $\begin{array}{l}\text { Quintile of financial wealth at the beginning of } 2008 \\
\text { computed for the entrepreneurs in } 2008 \text { and by gender. } \\
\text { Financial wealth net of financial debts (except mortgage for } \\
\text { home owners) }\end{array}$ & $\begin{array}{l}\text { INTEGRAAL } \\
\text { VERMOGENSBESTAND }\end{array}$ \\
\hline Self_income & $\begin{array}{l}1 \text { if the main source of incomes is self-employment in } 2007 \\
\text { (if not available, 2008) }\end{array}$ & PINKZELFST \\
\hline $\begin{array}{l}\text { Gross Household Incomes } \\
\text { (In G_H_I_n) }\end{array}$ & Gross Household Incomes in 2007 & $\begin{array}{l}\text { INTEGRAAL HUISHOUDENS } \\
\text { INKOMEN }\end{array}$ \\
\hline Home ownership & 1 if the individual is the owner of the house in 2007 & $\begin{array}{l}\text { INTEGRAAL HUISHOUDENS } \\
\text { INKOMEN }\end{array}$ \\
\hline $\begin{array}{l}\text { Business Wealth } \\
\text { (In_bw_n) }\end{array}$ & $\begin{array}{l}\text { Business wealth at the beginning of } 2008 \text {. For the } \\
\text { estimations we normalized this variable to avoid negative } \\
\text { values and take logarithm. Proxy for business success }\end{array}$ & $\begin{array}{l}\text { INTEGRAAL } \\
\text { VERMOGENSBESTAND }\end{array}$ \\
\hline Employees & 1 if the entrepreneur has employees in 2008, otherwise 0 & PINKZELFST \\
\hline
\end{tabular}

Source: Statistics Netherlands and Eurostat
Description Source 


\section{Online appendix}

Table B1 Estimation results of the multinomial logit model (exit to employment and retirement). Unmarried pure entrepreneurs; Model 1 and Model 2

\begin{tabular}{|c|c|c|c|c|}
\hline \multirow{3}{*}{ Male } & \multicolumn{2}{|c|}{ Model 1} & Model 2 & \multirow[b]{2}{*}{ Retirement } \\
\hline & Employment & Retirement & Employment & \\
\hline & $0.177276^{*}$ & $-0.221683^{* * *}$ & $0.177457^{*}$ & $-0.218711^{* * *}$ \\
\hline & $(0.084)$ & $(0.036)$ & $(0.084)$ & $(0.036)$ \\
\hline \multirow[t]{2}{*}{ Unemp rate } & $0.197599 * * *$ & $0.099402^{* * *}$ & $0.197766 * * *$ & $0.102321 * * *$ \\
\hline & $(0.028)$ & $(0.011)$ & $(0.028)$ & $(0.011)$ \\
\hline \multirow[t]{2}{*}{ Children } & $0.371397 * * *$ & $0.102183^{* *}$ & $0.371422 * * *$ & $0.102058 * *$ \\
\hline & (0.089) & $(0.037)$ & $(0.089)$ & $(0.037)$ \\
\hline \multirow[t]{2}{*}{ Age_months } & $0.198215^{* * *}$ & $0.229866 * * *$ & $0.190958 * *$ & $0.170256 * * *$ \\
\hline & $(0.051)$ & $(0.017)$ & $(0.062)$ & (0.019) \\
\hline \multirow[t]{2}{*}{ Age_months ${ }^{2}$} & $-0.000139 * * *$ & $-0.000144 * * *$ & $-0.000134 * *$ & $-0.000104 * * *$ \\
\hline & $(0.000)$ & $(0.000)$ & $(0.000)$ & $(0.000)$ \\
\hline \multirow[t]{2}{*}{ 1.sra_1 } & $0.455639 * *$ & $0.668949 * * *$ & & \\
\hline & $(0.165)$ & $(0.054)$ & & \\
\hline \multirow[t]{2}{*}{ 1.srab_1 } & & & $0.472032 * *$ & $0.749448^{* * *}$ \\
\hline & & & $(0.166)$ & $(0.054)$ \\
\hline \multirow[t]{2}{*}{ 1.srab2_1 } & & & 0.408487 & $0.316761^{* * *}$ \\
\hline & & & $(0.251)$ & $(0.074)$ \\
\hline \multirow[t]{2}{*}{ 2.qfwe_net_debt } & -0.138786 & $-0.107088^{*}$ & -0.138814 & $-0.108678^{*}$ \\
\hline & $(0.104)$ & $(0.053)$ & $(0.104)$ & $(0.053)$ \\
\hline \multirow[t]{2}{*}{ 3.qfwe_net_debt } & $-0.407817 * * *$ & $-0.115661 *$ & $-0.407861 * * *$ & $-0.117816^{*}$ \\
\hline & $(0.115)$ & $(0.052)$ & $(0.115)$ & $(0.053)$ \\
\hline \multirow[t]{2}{*}{ 4.qfwe_net_debt } & $-0.563009 * * *$ & 0.094236 & $-0.562920 * * *$ & 0.092943 \\
\hline & $(0.125)$ & $(0.051)$ & $(0.125)$ & $(0.051)$ \\
\hline \multirow[t]{2}{*}{ 5.qfwe_net_debt } & $-0.677557 * * *$ & $0.233028 * * *$ & $-0.677322 * * *$ & $0.232181^{* * *}$ \\
\hline & $(0.140)$ & $(0.054)$ & $(0.140)$ & $(0.054)$ \\
\hline \multirow[t]{2}{*}{ 1.self_income } & $-0.366600 * * *$ & $-0.299723 * * *$ & $-0.366474 * * *$ & $-0.299104 * * *$ \\
\hline & $(0.100)$ & $(0.041)$ & $(0.100)$ & $(0.041)$ \\
\hline \multirow[t]{2}{*}{ Construction } & 0.408048 & 0.011411 & 0.408147 & 0.013958 \\
\hline & $(0.260)$ & $(0.082)$ & $(0.260)$ & $(0.082)$ \\
\hline \multirow[t]{2}{*}{ Manufacturing } & $0.617579 *$ & $-0.426482 * * *$ & $0.617774 *$ & $-0.422052 * * *$ \\
\hline & $(0.284)$ & $(0.108)$ & $(0.284)$ & $(0.108)$ \\
\hline \multirow[t]{2}{*}{ Services } & $0.945219 * * *$ & $-0.112669 *$ & $0.945325 * * *$ & $-0.110408 *$ \\
\hline & $(0.188)$ & $(0.052)$ & $(0.188)$ & $(0.052)$ \\
\hline \multirow[t]{2}{*}{ Employees } & -0.083658 & $-0.371223 * * *$ & -0.083734 & $-0.373187 * * *$ \\
\hline & $(0.112)$ & $(0.045)$ & $(0.112)$ & $(0.045)$ \\
\hline \multirow[t]{2}{*}{ Tenure } & $0.068066 * * *$ & $0.034374 * * *$ & $0.068057^{* * *}$ & $0.034168 * * *$ \\
\hline & $(0.003)$ & $(0.001)$ & $(0.003)$ & $(0.001)$ \\
\hline \multirow[t]{2}{*}{ Home_ownership } & $-0.363449 * * *$ & -0.062821 & $-0.363353^{* * *}$ & -0.061232 \\
\hline & $(0.080)$ & $(0.035)$ & $(0.080)$ & $(0.035)$ \\
\hline In_GIH_n & $5.047679 * * *$ & 0.892929* & $5.046872 * * *$ & $0.891249 *$ \\
\hline & $(0.571)$ & $(0.362)$ & $(0.571)$ & $(0.362)$ \\
\hline In_bw_n & $-3.0 \mathrm{e}+00 * * *$ & $-1.7 e+00 * * *$ & $-3.0 \mathrm{e}+00 * * *$ & $-1.7 e+00 * * *$ \\
\hline & $(0.663)$ & $(0.271)$ & $(0.664)$ & $(0.271)$ \\
\hline _cons & $-1.0 \mathrm{e}+02 * * *$ & $-8.4 \mathrm{e}+01 * * *$ & $-1.0 \mathrm{e}+02 * * *$ & $-6.1 e+01 * * *$ \\
\hline & $(22.881)$ & $(8.998)$ & $(26.182)$ & $(9.420)$ \\
\hline Observations & 87,320 & 87,320 & 87,320 & 87,320 \\
\hline Pseudo R^2 & 0.09044 & 0.09044 & 0.09166 & 0.09166 \\
\hline Log Likelihood & $-1.9 e+04$ & $-1.9 e+04$ & $-1.9 e+04$ & $-1.9 e+04$ \\
\hline
\end{tabular}

Note: Model 1 and Model 2 do not include the interaction of SRA_1 (SRAb_1) with financial wealth. SRA: 1 from the year the individual reaches the SRA onwards. SRAb: 1 in the year the individual reaches the SRA; Srab2: 1 from the year after reaching the SRA. Standard errors in parenthesis. References categories: females, $1 . q f w e \_n e t$ debt, Agriculture. ${ }^{*} p<0.05 ;{ }^{* *} p<0.01 ;{ }^{* *} p<0.001$ 
Table B2 Estimation results of the multinomial logit model (exit to employment and retirement) of unmarried entrepreneurs by gender. Model 1

\begin{tabular}{|c|c|c|c|c|}
\hline & \multicolumn{2}{|c|}{ Employment } & \multicolumn{2}{|c|}{ Retirement } \\
\hline & Males & Females & Males & Females \\
\hline \multirow[t]{2}{*}{ Unemp. rate } & $0.210319 * * *$ & $0.180710^{* * *}$ & $0.087010 * * *$ & $0.127794 * * *$ \\
\hline & $(0.035)$ & $(0.046)$ & $(0.015)$ & $(0.018)$ \\
\hline \multirow[t]{2}{*}{ Children } & $0.467051 * * *$ & 0.127691 & 0.068028 & 0.094624 \\
\hline & $(0.106)$ & $(0.162)$ & $(0.045)$ & $(0.065)$ \\
\hline \multirow[t]{2}{*}{ Age_months } & $0.176896 * *$ & $0.236115^{* *}$ & $0.188828 * * *$ & $0.292695 * * *$ \\
\hline & $(0.064)$ & $(0.088)$ & $(0.022)$ & $(0.028)$ \\
\hline \multirow[t]{2}{*}{ Age_months ${ }^{2}$} & $-0.000126^{* *}$ & $-0.000162 * *$ & $-0.000117^{* * *}$ & $-0.000185^{* * *}$ \\
\hline & $(0.000)$ & $(0.000)$ & $(0.000)$ & $(0.000)$ \\
\hline \multirow[t]{2}{*}{ 1.sra_1 } & $0.514224 *$ & 0.332399 & $0.657559 * * *$ & $0.690933^{* * *}$ \\
\hline & $(0.207)$ & $(0.275)$ & $(0.070)$ & $(0.085)$ \\
\hline \multirow[t]{2}{*}{ 2.qfwe_net_debt } & -0.155301 & -0.103594 & -0.033234 & $-0.227501 * *$ \\
\hline & $(0.128)$ & $(0.178)$ & $(0.067)$ & $(0.086)$ \\
\hline \multirow[t]{2}{*}{ 3.qfwe_net_debt } & $-0.467960 * *$ & -0.297395 & -0.128446 & -0.100092 \\
\hline & $(0.143)$ & $(0.192)$ & $(0.068)$ & $(0.083)$ \\
\hline \multirow[t]{2}{*}{ 4.qfwe_net_debt } & $-0.573562 * * *$ & $-0.533133^{*}$ & 0.064832 & 0.131922 \\
\hline & $(0.155)$ & $(0.212)$ & $(0.067)$ & $(0.080)$ \\
\hline \multirow[t]{2}{*}{ 5.qfwe_net_debt } & $-0.715088 * * *$ & $-0.638728 * *$ & $0.211467 * *$ & $0.265334^{* *}$ \\
\hline & $(0.177)$ & $(0.232)$ & $(0.070)$ & $(0.084)$ \\
\hline \multirow[t]{2}{*}{ 1.self_income } & $-0.366789 * *$ & $-0.362902^{*}$ & $-0.268093 * * *$ & $-0.282152 * * *$ \\
\hline & (0.139) & $(0.144)$ & $(0.060)$ & $(0.058)$ \\
\hline \multirow[t]{2}{*}{ Construction } & 0.378716 & 0.866123 & 0.141746 & -0.573090 \\
\hline & $(0.285)$ & $(0.815)$ & $(0.091)$ & $(0.343)$ \\
\hline \multirow[t]{2}{*}{ Manufacturing } & 0.475862 & 0.832015 & $-0.348981 * *$ & $-0.586551 * *$ \\
\hline & $(0.336)$ & $(0.547)$ & (0.129) & $(0.202)$ \\
\hline \multirow[t]{2}{*}{ Services } & $0.961740 * * *$ & 0.738705 & 0.031430 & $-0.443127^{* * *}$ \\
\hline & $(0.217)$ & $(0.394)$ & $(0.066)$ & $(0.092)$ \\
\hline \multirow[t]{2}{*}{ employees } & -0.109747 & -0.059912 & $-0.394603 * * *$ & $-0.402553^{* * *}$ \\
\hline & (0.149) & $(0.170)$ & $(0.062)$ & $(0.065)$ \\
\hline \multirow[t]{2}{*}{ Tenure } & $0.070665 * * *$ & $0.064096 * * *$ & $0.031629 * * *$ & $0.038212^{* * *}$ \\
\hline & $(0.004)$ & $(0.005)$ & $(0.001)$ & $(0.002)$ \\
\hline \multirow[t]{2}{*}{ home_ownership } & $-0.439703 * * *$ & -0.203254 & $-0.100295^{*}$ & 0.011144 \\
\hline & $(0.100)$ & $(0.136)$ & (0.045) & $(0.056)$ \\
\hline \multirow[t]{2}{*}{ In_GIH_n } & $4.921101 * * *$ & $5.423269 * * *$ & 0.715877 & 0.997725 \\
\hline & $(0.696)$ & $(1.008)$ & $(0.466)$ & $(0.579)$ \\
\hline \multirow[t]{2}{*}{ In_bw_n } & $-2.4 e+00 * *$ & $-5.6 \mathrm{e}+00 * * *$ & $-1.8 \mathrm{e}+00 * * *$ & $-1.4 \mathrm{e}+00 * *$ \\
\hline & $(0.781)$ & $(1.596)$ & $(0.322)$ & $(0.497)$ \\
\hline \multirow[t]{2}{*}{ _cons } & $-1.0 \mathrm{e}+02 * * *$ & $-8.7 e+01^{*}$ & $-6.4 \mathrm{e}+01 * * *$ & $-1.1 \mathrm{e}+02 * * *$ \\
\hline & (28.103) & $(42.260)$ & $(11.387)$ & $(14.873)$ \\
\hline Observations & 57,486 & 29,834 & 57,486 & 29,834 \\
\hline Pseudo $R^{\wedge} \mathbf{2}$ & 0.08576 & 0.09796 & 0.08576 & 0.09796 \\
\hline Log Likelihood & $-1.2 e+04$ & $-7.2 e+03$ & $-1.2 e+04$ & $-7.2 e+03$ \\
\hline
\end{tabular}

Note: Model 1 does not include interactions of SRA_1 with other covariates. References categories: females, 1.qfwe, Agriculture. Standard errors in parenthesis. ${ }^{*} p<0.05 ;{ }^{* *} p<0.01 ;{ }^{* * *} p<0.001$ 
Table B3 Estimation results of the multinomial logit model (exit to employment and retirement) of unmarried entrepreneurs by gender. Model 2

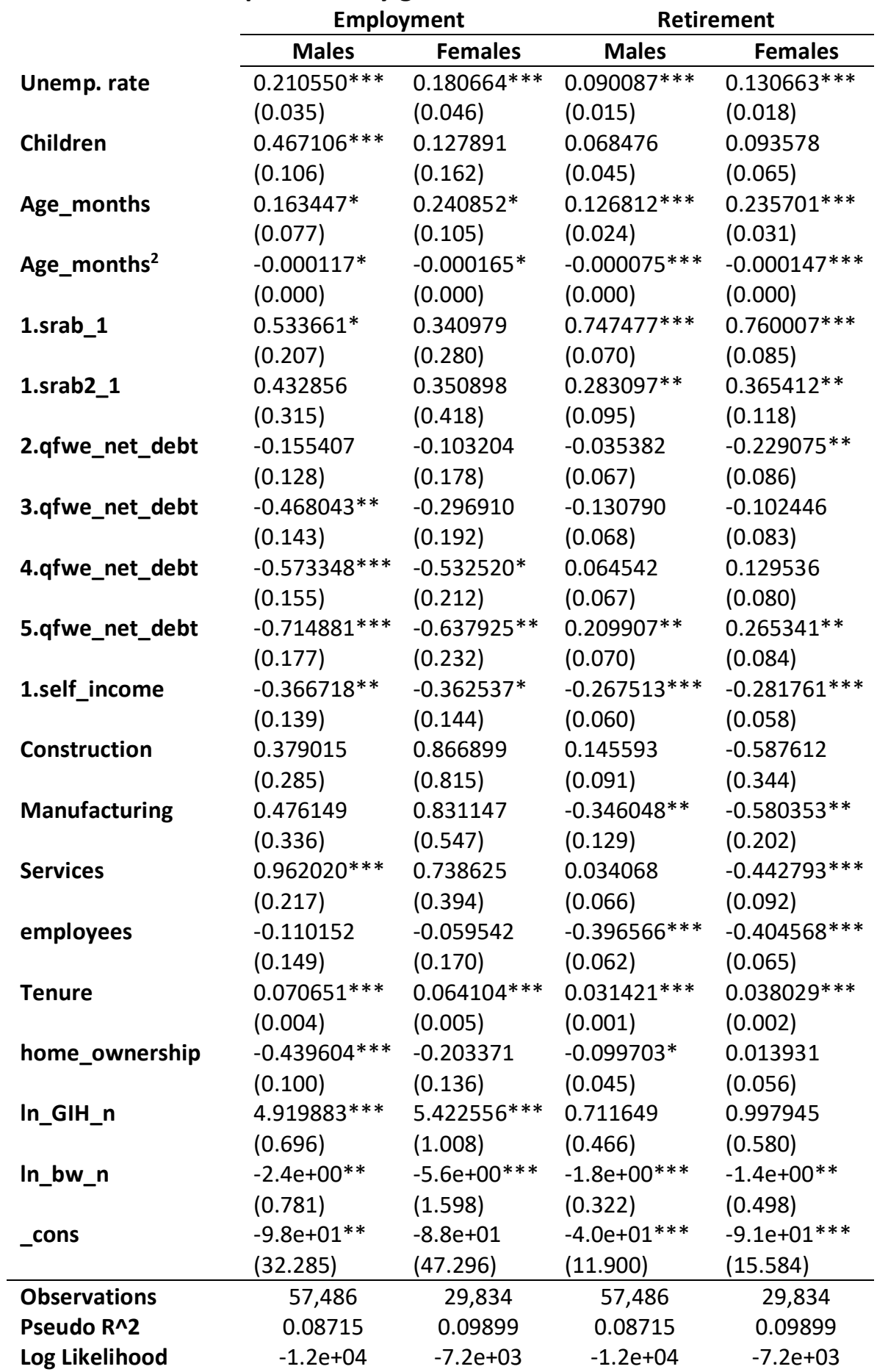

Note: Model 2 does not include the interaction of SRAb_1 with financial wealth. SRAb: 1 in the year the individual reaches the SRA; Srab2: 1 from the year after reaching the SRA. Standard errors in parenthesis. References categories: females, 1.qfwe_net_debt, Agriculture. * $p<0.05 ;{ }^{* *} p<0.01 ;{ }^{* * *} p<0.001$ 
Table B4 Estimation results of the multinomial logit model (exit to employment and retirement) unmarried entrepreneurs, all and by gender. Model 3

\begin{tabular}{|c|c|c|c|c|c|c|}
\hline \multirow[t]{2}{*}{. } & \multicolumn{3}{|c|}{ Employment } & \multicolumn{3}{|c|}{ Retirement } \\
\hline & All & Males & Females & All & Males & Females \\
\hline \multirow[t]{2}{*}{ Male } & $0.175148^{*}$ & & & $-0.221506 * * *$ & & \\
\hline & $(0.084)$ & & & $(0.036)$ & & \\
\hline \multirow[t]{2}{*}{ Unemp. rate } & $0.197399 * * *$ & $0.210389 * * *$ & $0.179783 * * *$ & $0.100331 * * *$ & $0.087691 * * *$ & $0.129259 * * *$ \\
\hline & $(0.028)$ & $(0.035)$ & $(0.046)$ & $(0.011)$ & $(0.015)$ & $(0.018)$ \\
\hline \multirow[t]{2}{*}{ Children } & $0.370460 * * *$ & $0.465182^{* * *}$ & 0.123129 & $0.104117^{* *}$ & 0.069727 & 0.095670 \\
\hline & $(0.089)$ & $(0.107)$ & $(0.162)$ & $(0.037)$ & $(0.045)$ & $(0.065)$ \\
\hline \multirow[t]{2}{*}{ Age_months } & $0.201452 * * *$ & $0.179433^{* *}$ & $0.239764 * *$ & $0.228420 * * *$ & $0.188445 * * *$ & $0.288859 * * *$ \\
\hline & $(0.051)$ & $(0.064)$ & $(0.087)$ & $(0.017)$ & $(0.022)$ & $(0.028)$ \\
\hline \multirow[t]{2}{*}{ Age_months ${ }^{2}$} & $-0.000141 * * *$ & $-0.000127^{* *}$ & $-0.000164 * *$ & $-0.000143 * * *$ & $-0.000116 * * *$ & $-0.000183 * * *$ \\
\hline & $(0.000)$ & $(0.000)$ & $(0.000)$ & $(0.000)$ & $(0.000)$ & $(0.000)$ \\
\hline \multirow[t]{2}{*}{ 1.sra_1 } & 0.060564 & 0.173080 & -0.188911 & $0.562784^{* * *}$ & $0.538142 * * *$ & $0.610689 * * *$ \\
\hline & $(0.241)$ & $(0.294)$ & $(0.424)$ & $(0.084)$ & (0.109) & $(0.134)$ \\
\hline \multirow[t]{2}{*}{ 2.qfwe_net_debt } & -0.159433 & -0.158725 & -0.156589 & $-0.329090 * * *$ & -0.187247 & $-0.558107 * * *$ \\
\hline & $(0.113)$ & $(0.140)$ & (0.193) & $(0.076)$ & $(0.096)$ & $(0.127)$ \\
\hline \multirow[t]{2}{*}{ 3.qfwe_net_debt } & $-0.567278 * * *$ & $-0.655107 * * *$ & -0.416332 & $-0.199808 * *$ & $-0.228924 *$ & -0.159973 \\
\hline & $(0.131)$ & $(0.167)$ & $(0.213)$ & $(0.074)$ & $(0.098)$ & $(0.115)$ \\
\hline \multirow[t]{2}{*}{ 4.qfwe_net_debt } & $-0.709220 * * *$ & $-0.671476 * * *$ & $-0.779122 * *$ & -0.003496 & -0.082295 & 0.097167 \\
\hline & $(0.141)$ & $(0.174)$ & $(0.245)$ & $(0.072)$ & $(0.096)$ & (0.109) \\
\hline \multirow[t]{2}{*}{ 5.qfwe_net_debt } & $-0.819234 * * *$ & $-0.857857 * * *$ & $-0.785629 * *$ & $0.336047 * * *$ & $0.289546 * *$ & $0.410208 * * *$ \\
\hline & (0.158) & $(0.201)$ & $(0.258)$ & $(0.070)$ & $(0.092)$ & $(0.108)$ \\
\hline \multirow[t]{2}{*}{ 1.self_income } & $-0.363127 * * *$ & $-0.364563 * *$ & $-0.360362^{*}$ & $-0.298123 * * *$ & $-0.263932 * * *$ & $-0.285487 * * *$ \\
\hline & $(0.100)$ & (0.139) & $(0.144)$ & $(0.041)$ & $(0.060)$ & $(0.058)$ \\
\hline \multirow[t]{2}{*}{ Construction } & 0.406303 & 0.378461 & 0.870290 & 0.010064 & 0.140414 & -0.567461 \\
\hline & $(0.260)$ & $(0.285)$ & $(0.815)$ & $(0.082)$ & (0.091) & $(0.344)$ \\
\hline \multirow[t]{2}{*}{ Manufacturing } & $0.610360 *$ & 0.466359 & 0.836505 & $-0.432597 * * *$ & $-0.350726 * *$ & $-0.600022 * *$ \\
\hline & $(0.284)$ & $(0.336)$ & $(0.547)$ & $(0.108)$ & (0.129) & $(0.202)$ \\
\hline \multirow[t]{2}{*}{ Services } & $0.943823 * * *$ & $0.963323 * * *$ & 0.736904 & $-0.115370 *$ & 0.029373 & $-0.439961 * * *$ \\
\hline & $(0.188)$ & $(0.217)$ & $(0.394)$ & $(0.052)$ & $(0.066)$ & $(0.092)$ \\
\hline \multirow[t]{2}{*}{ employees } & -0.083294 & -0.110422 & -0.054326 & $-0.368318 * * *$ & $-0.394065 * * *$ & $-0.396506 * * *$ \\
\hline & $(0.112)$ & (0.149) & $(0.170)$ & $(0.045)$ & $(0.062)$ & $(0.065)$ \\
\hline \multirow[t]{2}{*}{ Tenure } & $0.068018^{* * *}$ & $0.070551 * * *$ & $0.064264 * * *$ & $0.034319 * * *$ & $0.031593 * * *$ & $0.038094 * * *$ \\
\hline & $(0.003)$ & $(0.004)$ & $(0.005)$ & $(0.001)$ & $(0.001)$ & $(0.002)$ \\
\hline home_ownership & $-0.362392 * * *$ & $-0.438412 * * *$ & -0.201919 & -0.062754 & $-0.098890 *$ & 0.008765 \\
\hline & $(0.080)$ & $(0.100)$ & $(0.136)$ & $(0.035)$ & $(0.045)$ & $(0.056)$ \\
\hline In_GIH_n & $5.112006 * * *$ & $5.008128 * * *$ & $5.469771 * * *$ & $0.828629 *$ & 0.668828 & 0.898719 \\
\hline & $(0.571)$ & $(0.696)$ & $(1.009)$ & $(0.361)$ & $(0.465)$ & $(0.576)$ \\
\hline In_bw_n & $-3.0 \mathrm{e}+00 * * *$ & $-2.4 \mathrm{e}+00 * *$ & $-5.6 \mathrm{e}+00 * * *$ & $-1.7 e+00 * * *$ & $-1.8 \mathrm{e}+00 * * *$ & $-1.4 e+00 * *$ \\
\hline & $(0.657)$ & $(0.774)$ & $(1.579)$ & $(0.271)$ & $(0.322)$ & $(0.498)$ \\
\hline 1.sra_1\#2.qfwe_net_debt & 0.121938 & 0.020217 & 0.325476 & $0.431785^{* * *}$ & $0.304182 *$ & $0.624774 * * *$ \\
\hline & $(0.288)$ & $(0.353)$ & $(0.501)$ & $(0.106)$ & $(0.134)$ & $(0.173)$ \\
\hline 1.sra_1\#3.qfwe_net_debt & $0.755894^{* *}$ & $0.809358 *$ & 0.671648 & 0.174296 & 0.203088 & 0.128703 \\
\hline & $(0.282)$ & $(0.342)$ & $(0.501)$ & $(0.105)$ & $(0.136)$ & $(0.165)$ \\
\hline 1.sra_1\#4.qfwe_net_debt & $0.714335^{*}$ & 0.488244 & $1.150776^{*}$ & $0.202660 *$ & $0.290405^{*}$ & 0.081425 \\
\hline & $(0.302)$ & $(0.376)$ & $(0.515)$ & $(0.101)$ & $(0.132)$ & $(0.158)$ \\
\hline 1.sra_1\#5.qfwe_net_debt & $0.703905^{*}$ & 0.666095 & 0.808167 & $-0.217452 *$ & -0.155788 & $-0.325367^{*}$ \\
\hline & $(0.320)$ & $(0.396)$ & $(0.547)$ & $(0.100)$ & $(0.129)$ & $(0.159)$ \\
\hline _cons & $-1.1 \mathrm{e}+02 * * *$ & $-1.0 \mathrm{e}+02 * * *$ & $-8.9 e+01^{*}$ & $-8.2 \mathrm{e}+01 * * *$ & $-6.3 e+01 * * *$ & $-1.1 \mathrm{e}+02 * * *$ \\
\hline & $(22.843)$ & $(28.049)$ & $(42.206)$ & (9.000) & $(11.392)$ & $(14.852)$ \\
\hline Observations & 87,320 & 57,486 & 29,834 & 87,320 & 57,486 & 29,834 \\
\hline Pseudo R^2 & 0.09183 & 0.08684 & 0.10039 & 0.09183 & 0.08684 & 0.10039 \\
\hline Log Likelihood & $-1.9 e+04$ & $-1.2 e+04$ & $-7.2 e+03$ & $-1.9 e+04$ & $-1.2 e+04$ & $-7.2 e+03$ \\
\hline
\end{tabular}


Table B5 Test for differences in Average Marginal Effects on the exists from self-employment to retirement by financial wealth level for all, men and women. Each quintile versus the first quintile of financial wealth

\begin{tabular}{clll} 
& \multicolumn{1}{c}{ All } & Men & Women \\
\cline { 2 - 4 } (2 vs 1) & 0.015024 & 0.011351 & 0.019889 \\
SE & $(0.005)$ & $(0.006)$ & $(0.009)$ \\
p-value & 0.002144 & 0.051335 & 0.024907 \\
(3 vs 1) & 0.004313 & 0.004588 & 0.003661 \\
SE & $(0.005)$ & $(0.006)$ & $(0.009)$ \\
p-value & 0.368515 & 0.412223 & 0.68356 \\
(4 vs 1) & 0.01191 & 0.013044 & 0.009433 \\
SE & $(0.005)$ & $(0.006)$ & $(0.010)$ \\
p-value & 0.019278 & 0.027251 & 0.324902 \\
(5 vs 1) & -0.00675 & -0.00397 & -0.01305 \\
SE & $(0.005)$ & $(0.006)$ & $(0.010)$ \\
p-value & 0.202249 & 0.512712 & 0.20375 \\
\hline & & &
\end{tabular}


Table B6 Estimation results of the In(non-negative profits+1) using OLS. Model 1 and Model 2. Unmarried entrepreneurs and by gender

\begin{tabular}{|c|c|c|c|c|c|c|}
\hline \multirow{4}{*}{ Male } & \multicolumn{3}{|c|}{ Model 1} & \multicolumn{3}{|c|}{ Model 2} \\
\hline & All & Men & Women & All & Men & Women \\
\hline & $0.144852 * * *$ & & & $0.145248 * * *$ & & \\
\hline & $(0.011116)$ & & & $(0.011115)$ & & \\
\hline \multirow[t]{2}{*}{ Unemp. Rate } & 0.002310 & -0.000614 & 0.006856 & 0.002519 & -0.000464 & 0.007221 \\
\hline & $(0.003586)$ & $(0.004364)$ & $(0.006263)$ & $(0.003586)$ & $(0.004363)$ & $(0.006265)$ \\
\hline \multirow[t]{2}{*}{ Children } & $0.160420^{* * *}$ & $0.196320 * * *$ & $0.056257^{* *}$ & $0.160157^{* * *}$ & $0.196258 * * *$ & $0.055707^{* *}$ \\
\hline & $(0.010849)$ & $(0.012671)$ & (0.021034) & $(0.010848)$ & $(0.012670)$ & $(0.021033)$ \\
\hline \multirow[t]{2}{*}{ Age_months/100 } & $2.387058 * * *$ & $2.627139 * * *$ & $2.094852^{*}$ & 0.745911 & 0.870850 & 0.676058 \\
\hline & $(0.488733)$ & (0.602792) & $(0.833806)$ & (0.575029) & $(0.710841)$ & $(0.977468)$ \\
\hline \multirow[t]{2}{*}{ (Age_months/100)^2 } & $-0.173298 * * *$ & $-0.190155^{* * *}$ & $-0.152161 * *$ & -0.061954 & -0.071444 & -0.055132 \\
\hline & $(0.031964)$ & (0.039455) & $(0.054450)$ & $(0.038036)$ & $(0.047047)$ & $(0.064586)$ \\
\hline \multirow[t]{2}{*}{$1 . s r a b 2$} & $-0.102831 * * *$ & $-0.099368 * * *$ & $-0.101330 * *$ & & & \\
\hline & $(0.019302)$ & $(0.023500)$ & $(0.033663)$ & & & \\
\hline \multirow[t]{2}{*}{ 1.srac } & & & & -0.022164 & -0.014346 & -0.035374 \\
\hline & & & & (0.015009) & $(0.018132)$ & $(0.026553)$ \\
\hline \multirow[t]{2}{*}{ 1.srac1 } & & & & $-0.076602 * * *$ & $-0.067456^{* *}$ & $-0.086080^{*}$ \\
\hline & & & & $(0.021556)$ & $(0.026145)$ & $(0.037861)$ \\
\hline \multirow[t]{2}{*}{ 1.srac2 } & & & & $-0.211596 * * *$ & $-0.211422 * * *$ & $-0.203176 * * *$ \\
\hline & & & & $(0.028357)$ & $(0.034517)$ & $(0.049534)$ \\
\hline \multirow[t]{2}{*}{ 2.qr_fw_net_debt } & 0.010860 & -0.004395 & 0.028871 & 0.010739 & -0.004516 & 0.028814 \\
\hline & $(0.013505)$ & $(0.016612)$ & $(0.023110)$ & $(0.013503)$ & $(0.016608)$ & $(0.023107)$ \\
\hline \multirow[t]{2}{*}{ 3.qr_fw_net_debt } & 0.002559 & 0.027983 & -0.047220 & 0.002343 & 0.028018 & -0.047715 \\
\hline & $(0.014040)$ & $(0.016910)$ & $(0.025031)$ & $(0.014038)$ & $(0.016906)$ & $(0.025028)$ \\
\hline \multirow[t]{2}{*}{ 4.qr_fw_net_debt } & $-0.135900 * * *$ & $-0.085440 * * *$ & $-0.227193^{* * *}$ & $-0.136005^{* * *}$ & $-0.085084 * * *$ & $-0.228103^{* * *}$ \\
\hline & $(0.015345)$ & (0.018538) & $(0.027161)$ & $(0.015342)$ & (0.018534) & $(0.027160)$ \\
\hline \multirow[t]{2}{*}{ 1.self_income } & $1.040693 * * *$ & $1.056196 * * *$ & $1.013533 * * *$ & $1.041317^{* * *}$ & $1.056426 * * *$ & $1.014473^{* * *}$ \\
\hline & $(0.015313)$ & $(0.021723)$ & $(0.022325)$ & $(0.015312)$ & (0.021719) & $(0.022327)$ \\
\hline \multirow[t]{2}{*}{ Construction } & $-0.181366^{* * *}$ & $-0.226637^{* * *}$ & $-0.284804^{*}$ & $-0.180851^{* * *}$ & $-0.225938^{* * *}$ & $-0.285621^{*}$ \\
\hline & $(0.024871)$ & $(0.026281)$ & $(0.113364)$ & $(0.024867)$ & $(0.026277)$ & $(0.113355)$ \\
\hline \multirow[t]{2}{*}{ Manufacturing } & $-0.260085^{* * *}$ & $-0.246323 * * *$ & $-0.417509 * * *$ & $-0.259531^{* * *}$ & $-0.245869 * * *$ & $-0.416431 * * *$ \\
\hline & (0.029397) & $(0.032857)$ & $(0.066202)$ & $(0.029392)$ & $(0.032849)$ & $(0.066196)$ \\
\hline \multirow[t]{2}{*}{ Services } & $-0.139529 * * *$ & $-0.188845^{* * *}$ & $-0.092253^{*}$ & $-0.138966 * * *$ & $-0.188153^{* * *}$ & $-0.091582^{*}$ \\
\hline & $(0.017358)$ & $(0.019555)$ & (0.040939) & $(0.017356)$ & $(0.019551)$ & $(0.040938)$ \\
\hline \multirow[t]{2}{*}{ Employees } & $0.062324 * * *$ & $0.156698^{* * *}$ & $-0.066481^{* *}$ & $0.062079 * * *$ & $0.156150^{* * *}$ & $-0.066389 * *$ \\
\hline & $(0.015214)$ & $(0.019758)$ & $(0.024243)$ & $(0.015211)$ & $(0.019754)$ & $(0.024240)$ \\
\hline \multirow[t]{2}{*}{ Tenure } & $0.001240 * * *$ & 0.000435 & $0.002658^{* * *}$ & $0.001209 * * *$ & 0.000401 & $0.002633^{* * *}$ \\
\hline & $(0.000314)$ & $(0.000383)$ & $(0.000547)$ & $(0.000314)$ & $(0.000383)$ & $(0.000547)$ \\
\hline \multirow[t]{2}{*}{ home_ownership } & $0.164179 * * *$ & $0.169485^{* * *}$ & $0.154352 * * *$ & $0.164531 * * *$ & $0.169712^{* * *}$ & $0.154922 * * *$ \\
\hline & $(0.010404)$ & $(0.012582)$ & $(0.018435)$ & $(0.010402)$ & (0.012579) & $(0.018434)$ \\
\hline In_GIH_n & $8.145006 * * *$ & $8.527806 * * *$ & $7.130507 * * *$ & $8.145492^{* * *}$ & $8.526854 * * *$ & $7.133992 * * *$ \\
\hline & $(0.121190)$ & $(0.142338)$ & $(0.227731)$ & $(0.121173)$ & $(0.142315)$ & $(0.227723)$ \\
\hline In_bw_n & $1.674809 * * *$ & $1.432685^{* * *}$ & $2.418942 * * *$ & $1.673230 * * *$ & $1.430226 * * *$ & $2.419310 * * *$ \\
\hline & $(0.082062)$ & $(0.091248)$ & $(0.182206)$ & $(0.082046)$ & $(0.091228)$ & $(0.182185)$ \\
\hline _cons & $-1.4 \mathrm{e}+02 * * *$ & $-1.4 \mathrm{e}+02 * * *$ & $-1.3 \mathrm{e}+02 * * *$ & $-1.3 \mathrm{e}+02 * * *$ & $-1.3 e+02 * * *$ & $-1.3 e+02 * * *$ \\
\hline & $(2.657966)$ & (3.178623) & $(4.925401)$ & $(2.882206)$ & $(3.469617)$ & $(5.264159)$ \\
\hline Observations & 68,311 & 44,957 & 23,354 & 68,311 & 44,957 & 23,354 \\
\hline r2 & 0.18 & 0.18 & 0.16 & 0.18 & 0.18 & 0.16 \\
\hline r2_a & 0.18 & 0.18 & 0.16 & 0.18 & 0.18 & 0.16 \\
\hline Log Likelihood & $-113,506.93$ & $-73,811.69$ & $-39,540.05$ & $-113,492.19$ & $-73,800.45$ & $-39,536.09$ \\
\hline
\end{tabular}


Table B7 Estimation results of the In(non-negative profits+1) using OLS. Model 3. Unmarried entrepreneurs and by gender

Unemp. Rate

Children

Age_months/100

(Age_months/100)^2

1.srab2

2.qr_fw_net_debt

3.qr_fw_net_debt

4.qr_fw_net_debt

1.srab2\#2.qr_fw_net_debt

1.srab2\#3.qr_fw_net_debt

1.srab2\#4.qr_fw_net_debt

1.self_income

Construction

Manufacturing

Services

Employees

Tenure

home_ownership

In_GIH_n

In_bw_n

Model3

\begin{tabular}{|c|c|c|}
\hline All & Men & Women \\
\hline \multicolumn{3}{|l|}{$0.144805^{* * *}$} \\
\hline (0.011116) & & \\
\hline 0.002350 & -0.000474 & 0.007077 \\
\hline (0.003587) & $(0.004364)$ & $(0.006263)$ \\
\hline $0.160310 * * *$ & $0.196047^{* * *}$ & $0.056782^{* *}$ \\
\hline (0.010849) & (0.012670) & $(0.021032)$ \\
\hline $2.417250 * * *$ & $2.663762 * * *$ & $2.070723^{*}$ \\
\hline (0.488865) & $(0.602983)$ & $(0.833882)$ \\
\hline$-0.175265^{* * *}$ & $-0.192535 * * *$ & $-0.150611^{* *}$ \\
\hline (0.031973) & $(0.039468)$ & $(0.054455)$ \\
\hline$-0.112088 * * *$ & $-0.098853^{* *}$ & $-0.134964 * *$ \\
\hline (0.027393) & $(0.033421)$ & $(0.047521)$ \\
\hline 0.016631 & 0.018248 & 0.006345 \\
\hline (0.015616) & (0.019139) & $(0.026886)$ \\
\hline 0.002078 & 0.017696 & -0.031001 \\
\hline (0.016254) & $(0.019511)$ & $(0.029154)$ \\
\hline$-0.153330 * * *$ & $-0.099115^{* * *}$ & $-0.253456 * * *$ \\
\hline (0.017566) & $(0.021110)$ & $(0.031431)$ \\
\hline-0.022461 & $-0.091313^{*}$ & 0.086122 \\
\hline (0.031068) & $(0.038498)$ & $(0.052543)$ \\
\hline 0.002463 & 0.039380 & -0.055685 \\
\hline$(0.031560)$ & $(0.038206)$ & (0.055644) \\
\hline 0.061895 & 0.048466 & 0.094260 \\
\hline (0.031788) & $(0.038312)$ & (0.056629) \\
\hline $1.040680 * * *$ & $1.055369 * * *$ & $1.014872 * * *$ \\
\hline (0.015314) & $(0.021723)$ & $(0.022333)$ \\
\hline$-0.180788 * * *$ & $-0.225738 * * *$ & $-0.287026^{*}$ \\
\hline$(0.024871)$ & $(0.026279)$ & $(0.113352)$ \\
\hline$-0.259710 * * *$ & $-0.246062 * * *$ & $-0.419352 * * *$ \\
\hline (0.029398) & $(0.032853)$ & $(0.066202)$ \\
\hline$-0.138923 * * *$ & $-0.188252 * * *$ & $-0.092864 *$ \\
\hline (0.017359) & (0.019553) & (0.040935) \\
\hline $0.062577 * * *$ & $0.157602 * * *$ & $-0.065849 * *$ \\
\hline (0.015214) & $(0.019757)$ & $(0.024241)$ \\
\hline $0.001263 * * *$ & 0.000475 & $0.002666 * * *$ \\
\hline$(0.000314)$ & $(0.000383)$ & $(0.000547)$ \\
\hline $0.164339 * * *$ & $0.169225^{* * *}$ & $0.155404^{* * *}$ \\
\hline (0.010404) & $(0.012581)$ & $(0.018436)$ \\
\hline $8.149462 * * *$ & $8.536711^{* * *}$ & $7.126003 * * *$ \\
\hline (0.121210) & $(0.142338)$ & $(0.227778)$ \\
\hline $1.671827^{* * *}$ & $1.429456 * * *$ & $2.401789 * * *$ \\
\hline (0.082069) & (0.091241) & (0.182274) \\
\hline$-1.4 \mathrm{e}+02 * * *$ & $-1.4 \mathrm{e}+02 * * *$ & $-1.3 e+02 * * *$ \\
\hline (2.658615) & (3.178937) & $(4.927920)$ \\
\hline 68,311 & 44,957 & 23,354 \\
\hline 0.18 & 0.18 & 0.16 \\
\hline 0.18 & 0.18 & 0.16 \\
\hline$-113,502.98$ & $-73,803.21$ & $-39,535.01$ \\
\hline
\end{tabular}

_cons

$-113,502.98$

$-73,803.21$

39,535.01

Log Likelihood parenthesis. ${ }^{*} p<0.05 ;{ }^{* *} p<0.01 ;{ }^{* * *} p<0.001$ 
Table B8 Robustness check: Average Marginal Effects of SRA on transitions from Selfemployment to Retirement. Model 1 for all, men and women

\begin{tabular}{|c|c|c|c|c|}
\hline \multirow{3}{*}{ SRA (AII) } & (1) & (2) & (3) & (4) \\
\hline & $0.030902 * * *$ & $0.030794 * * *$ & $0.031077^{* * *}$ & $0.0310184 * * *$ \\
\hline & $(0.003)$ & $(0.003)$ & $(0.003)$ & $(0.0027813)$ \\
\hline Observations & 87,387 & 87,320 & 86,326 & 86,256 \\
\hline \multirow[t]{2}{*}{ SRA (Men) } & $0.027309 * * *$ & $0.027330 * * *$ & $0.028193^{* * *}$ & $0.028198 * * *$ \\
\hline & $(0.003)$ & $(0.003)$ & $(0.003)$ & $(0.003)$ \\
\hline Observations & 57,521 & 57,486 & 59,638 & 59,588 \\
\hline SRA (Women) & $\begin{array}{l}0.037902 * * * \\
(0.005)\end{array}$ & $\begin{array}{l}0.037601^{* * *} \\
(0.005)\end{array}$ & $\begin{array}{l}0.037424 * * * \\
(0.005)\end{array}$ & $\begin{array}{l}0.036523 * * * \\
(0.005)\end{array}$ \\
\hline Observations & 29,866 & 29,834 & 26,688 & 26,668 \\
\hline $\begin{array}{l}\text { Definition of pure } \\
\text { entrepreneur }\end{array}$ & \multicolumn{2}{|c|}{ No occupational pension } & \multicolumn{2}{|c|}{ No past job } \\
\hline Financial wealth & gross of debt & net of debt & gross of debt & net of debt \\
\hline
\end{tabular}

Table B9 Robustness check: Average Marginal Effects of SRA on the transition from selfemployment to retirement over quintiles of financial wealth. Model 3 for men and women

\begin{tabular}{|c|c|c|c|c|}
\hline & (1) & (2) & (3) & (4) \\
\hline & \multicolumn{4}{|c|}{ Men } \\
\hline \multirow[t]{2}{*}{ 1.qfw } & $0.024055^{* * *}$ & $0.022227^{* * *}$ & $0.025412^{* * *}$ & $0.023991 * * *$ \\
\hline & $(0.005)$ & $(0.005)$ & $(0.005)$ & $(0.005)$ \\
\hline \multirow[t]{2}{*}{ 2.qfw } & $0.034809 * * *$ & $0.033578 * * *$ & $0.033809 * * *$ & $0.033595 * * *$ \\
\hline & $(0.005)$ & $(0.005)$ & $(0.005)$ & $(0.005)$ \\
\hline \multirow[t]{2}{*}{ 3.qfw } & $0.027906 * * *$ & $0.026815^{* * *}$ & $0.029054^{* * *}$ & $0.027066 * * *$ \\
\hline & $(0.005)$ & $(0.004)$ & $(0.004)$ & $(0.004)$ \\
\hline \multirow[t]{2}{*}{ 4.qfw } & $0.032358 * * *$ & $0.035271 * * *$ & $0.033369 * * *$ & $0.035043 * * *$ \\
\hline & $(0.005)$ & $(0.005)$ & $(0.005)$ & $(0.005)$ \\
\hline \multirow[t]{3}{*}{$5 . q f w$} & $0.016448 * *$ & $0.018253^{* * *}$ & $0.018397 * * *$ & $0.021301 * * *$ \\
\hline & $(0.005)$ & $(0.005)$ & $(0.005)$ & $(0.005)$ \\
\hline & \multicolumn{4}{|c|}{ Women } \\
\hline \multirow[t]{2}{*}{ 1.qfw } & $0.044826 * * *$ & $0.032415^{* * *}$ & $0.037352 * * *$ & $0.026003 * *$ \\
\hline & $(0.007)$ & $(0.008)$ & $(0.008)$ & $(0.008)$ \\
\hline \multirow[t]{2}{*}{ 2.qfw } & $0.049052 * * *$ & $0.052304 * * *$ & $0.046014^{* * *}$ & $0.052917 * * *$ \\
\hline & $(0.007)$ & $(0.007)$ & $(0.007)$ & $(0.008)$ \\
\hline \multirow[t]{2}{*}{ 3.qfw } & $0.037141 * * *$ & $0.036076^{* * *}$ & $0.038790 * * *$ & $0.033117 * * *$ \\
\hline & $(0.008)$ & $(0.007)$ & $(0.008)$ & $(0.008)$ \\
\hline \multirow[t]{2}{*}{ 4.qfw } & $0.035462 * * *$ & $0.041848 * * *$ & $0.037536 * * *$ & $0.043591 * * *$ \\
\hline & $(0.008)$ & $(0.008)$ & (0.009) & $(0.009)$ \\
\hline \multirow[t]{2}{*}{ 5.qfw } & 0.016626 & $0.019362 *$ & $0.024911^{*}$ & $0.026343^{* *}$ \\
\hline & $(0.010)$ & $(0.009)$ & $(-0.01)$ & $(0.010)$ \\
\hline \multicolumn{5}{|l|}{ tion of pure } \\
\hline $\begin{array}{l}\text { preneur } \\
\text { gcial wealth }\end{array}$ & Gross of debt & Net of debt & Gross of debt & Net of debt \\
\hline
\end{tabular}


Table B10 Robustness check: Marginal Effects of SRA on profits using OLS. Model 1 for all, men and women

\begin{tabular}{|c|c|c|c|c|}
\hline & & & & \\
\hline & (1) & (2) & (3) & (4) \\
\hline \multirow{2}{*}{ SRAb (All) } & $-0.102828 * * *$ & $-0.102831 * * *$ & $-0.085266 * * *$ & $-0.084895 * * *$ \\
\hline & $(0.019300)$ & $(0.019302)$ & $(0.019018)$ & $(0.019015)$ \\
\hline Observations & 68,311 & 68,311 & 67,725 & 67,725 \\
\hline \multirow[t]{2}{*}{ SRAb (Men) } & $-0.099534 * * *$ & $-0.099368 * * *$ & $-0.085179 * * *$ & $-0.084629 * * *$ \\
\hline & $(0.023497)$ & $(0.023500)$ & $(0.022794)$ & $(0.022789)$ \\
\hline Observations & $44,957.00$ & 44,957 & 46,859 & 46,859 \\
\hline \multirow[t]{2}{*}{ SRAb (Women) } & $-0.099574 * *$ & $-0.101330 * *$ & $-0.071442 *$ & $-0.072558 *$ \\
\hline & $(0.033665)$ & $(0.033663)$ & $(0.034331)$ & $(0.034326)$ \\
\hline Observations & 23,354 & 23,354 & 20,866 & 20,866 \\
\hline Definition of pure entrepreneur & \multicolumn{2}{|c|}{ No occupational pension } & \multicolumn{2}{|c|}{ No past job } \\
\hline Financial wealth & gross of debt & net of debt & gross of debt & net of debt \\
\hline
\end{tabular}

Table B11 Robustness check: Marginal Effects of SRA over financial wealth on profits using OLS. Model 3 for men and women

\begin{tabular}{|c|c|c|c|c|}
\hline & (1) & (2) & (3) & (4) \\
\hline & \multicolumn{4}{|c|}{ Men } \\
\hline 1.qfw & $\begin{array}{c}-0.138352^{* * *} \\
(0.033546)\end{array}$ & $\begin{array}{c}-0.098853^{* *} \\
(0.033421)\end{array}$ & $\begin{array}{l}-0.065272 \\
(0.033659)\end{array}$ & $\begin{array}{l}-0.045535 \\
(0.033128)\end{array}$ \\
\hline \multirow[t]{2}{*}{ 2.qfw } & $-0.148727^{* * *}$ & $-0.190167^{* * *}$ & $-0.127766^{* * *}$ & $-0.154963 * * *$ \\
\hline & $(0.032408)$ & $(0.033155)$ & $(0.031375)$ & $(0.032360)$ \\
\hline \multirow[t]{2}{*}{ 3.qfw } & $-0.073763 *$ & -0.059474 & $-0.091870 * *$ & -0.048168 \\
\hline & (0.033009) & (0.032769) & (0.031724) & $(0.031507)$ \\
\hline \multirow[t]{3}{*}{ 4.qfw } & -0.032600 & -0.050388 & -0.050046 & $-0.090482 * *$ \\
\hline & $(0.033470)$ & $(0.033056)$ & $(0.031960)$ & $(0.031615)$ \\
\hline & \multicolumn{4}{|c|}{ Women } \\
\hline \multirow[t]{2}{*}{ 1.qfw } & -0.079248 & $-0.134964^{* *}$ & 0.032004 & -0.066258 \\
\hline & $(0.046946)$ & $(0.047521)$ & $(0.049208)$ & (0.049204) \\
\hline \multirow[t]{2}{*}{ 2.qfw } & $-0.100826^{*}$ & -0.048842 & -0.036440 & -0.018952 \\
\hline & $(0.046454)$ & $(0.044736)$ & $(0.047782)$ & $(0.046308)$ \\
\hline \multirow[t]{2}{*}{ 3.qfw } & $-0.197626^{* * *}$ & $-0.190649 * * *$ & $-0.225164^{* * *}$ & $-0.134827^{* *}$ \\
\hline & $(0.047086)$ & $(0.048662)$ & (0.047744) & $(0.049631)$ \\
\hline \multirow[t]{2}{*}{ 4.qfw } & -0.006623 & -0.040704 & -0.044235 & -0.082799 \\
\hline & $(0.049920)$ & $(0.049816)$ & $(0.049377)$ & $(0.049262)$ \\
\hline \multirow{2}{*}{$\begin{array}{l}\text { Definition of pure entepreneur } \\
\text { Financial wealth }\end{array}$} & \multicolumn{2}{|c|}{ No occupational pension } & \multicolumn{2}{|c|}{ No past job } \\
\hline & Gross of debt & Net of debt & Gross of debt & Net of debt \\
\hline
\end{tabular}


Table B12 Robustness check: Coefficients and Average Marginal Effects of SRA on transitions from Self-employment to Retirement. Model 1 for all, men and women. Unmarried pure selfemployed (excluding directors)

\begin{tabular}{ccccccc} 
& \multicolumn{2}{c}{ All } & \multicolumn{2}{c}{ men } & \multicolumn{2}{c}{ women } \\
\cline { 2 - 7 } sra_1 & dydx & Coef. & dydx & Coef. & dydx & Coef. \\
\cline { 2 - 7 } & $0.03619728^{* * *}$ & $0.618^{* * *}$ & $0.0289^{* * *}$ & $0.6307^{* * *}$ & $0.0468^{* * *}$ & $0.6167^{* * *}$ \\
Observations & $(0.0028)$ & $(0.0439)$ & $(0.0032312)$ & $(0.0642)$ & $(0.00499)$ & $(0.0594729)$ \\
\cline { 2 - 7 } & 110,120 & 110,120 & 63,184 & 63,184 & 46,936 & 46,936
\end{tabular}

Note: Controls included are: Unemployment rate by gender, children, age_months, age_months2, quintile financial wealth net of debt, industry, homeownership, In_GIH, entrepreneur dummy. For men (women): 90\% (63.33\%) of the observations corresponds to entrepreneurs, $0.17 \%(0.75 \%)$ to family members and $9.73 \%(35.92 \%)$ to freelance workers.

Standard errors in parenthesis. . $p<0.05 ;{ }^{* *} p<0.01 ; * * * 0.001$

Table B13 Robustness check: Average Marginal Effects of SRA on the transition from selfemployment to retirement over quintiles of financial wealth. Model 3 for men and women. Unmarried pure self-employed (excluding directors)

\begin{tabular}{cccc} 
& all & men & women \\
\cline { 2 - 4 } 1.qfw & $0.0359663^{* * *}$ & $0.0299544^{* * *}$ & $0.0444961^{* * *}$ \\
& $(0.0044427)$ & $(0.005176)$ & $(0.0074816)$ \\
2.qfw & $0.0447579^{* * *}$ & $0.0314488^{* * *}$ & $0.0632634^{* * *}$ \\
& $(0.004456)$ & $(0.0049416)$ & $(0.0077649)$ \\
3.qfw & $0.0359665^{* * *}$ & $0.0299287^{* * *}$ & $0.044613^{* * *}$ \\
& $(0.004007)$ & $(0.0045544)$ & $(0.0072814)$ \\
4.qfw & $0.0409^{* * *}$ & $0.0342779^{* * *}$ & $0.050948^{* * *}$ \\
& $(0.0042912)$ & $(0.0049313)$ & $(0.0079098)$ \\
5.qfw & $0.0239162^{* * *}$ & $0.0192572^{* * *}$ & $0.0296836 * *$ \\
& $(0.0044232)$ & $(0.0051347)$ & $(0.0079459)$ \\
\hline Obs. & 110,120 & 63,184 & 46,936 \\
\hline
\end{tabular}

Note: see Note table B12 


\section{Latest CeRP Working Papers}

\begin{tabular}{|c|c|}
\hline $\mathrm{N}^{\circ} 182 / 18$ & $\begin{array}{l}\text { Amparo Nagore García } \\
\text { Mariacristina Rossi } \\
\text { Arthur van Soest }\end{array}$ \\
\hline $\mathrm{N}^{\circ} 181 / 18$ & Nikola Altiparmakov \\
\hline $\mathrm{N}^{\circ} 180 / 18$ & $\begin{array}{l}\text { Elsa Fornero } \\
\text { Noemi Oggero } \\
\text { Riccardo Puglisi }\end{array}$ \\
\hline $\mathrm{N}^{\circ} 179 / 18$ & $\begin{array}{l}\text { Alessandro Milazzo } \\
\text { Elena Vigna }\end{array}$ \\
\hline $\mathrm{N}^{\circ} 178 / 18$ & $\begin{array}{l}\text { Dora Gambardella } \\
\text { Maria Cristina Rossi } \\
\text { Riccardo Salomone }\end{array}$ \\
\hline $\mathrm{N}^{\circ} 177 / 18$ & $\begin{array}{l}\text { Mariacristina Rossi } \\
\text { Dario Sansone } \\
\text { Arthur van Soest } \\
\text { Costanza Torricelli }\end{array}$ \\
\hline $\mathrm{N}^{\circ} 176 / 18$ & $\begin{array}{l}\text { Elsa Fornero } \\
\text { Mariacristina Rossi } \\
\text { Cesira Urzì Brancati }\end{array}$ \\
\hline $\mathrm{N}^{\circ} 175 / 18$ & $\begin{array}{l}\text { Claudio Morana } \\
\text { Giacomo Sbrana }\end{array}$ \\
\hline$N^{\circ} 174 / 17$ & $\begin{array}{l}\text { Elsa Fornero } \\
\text { Mariacristina Rossi } \\
\text { Serena Trucchi }\end{array}$ \\
\hline $\mathrm{N}^{\circ} 173 / 17$ & $\begin{array}{l}\text { Annamaria Lusardi } \\
\text { Olivia S. Mitchell } \\
\text { Noemi Oggero }\end{array}$ \\
\hline $\mathrm{N}^{\circ} 172 / 17$ & $\begin{array}{l}\text { Giovanni Gallo } \\
\text { Costanza Torricelli } \\
\text { Arthur van Soest }\end{array}$ \\
\hline $\mathrm{N}^{\circ} 171 / 17$ & $\begin{array}{l}\text { Elsa Fornero } \\
\text { Anna Lo Prete }\end{array}$ \\
\hline $\mathrm{N}^{\circ} 170 / 17$ & $\begin{array}{l}\text { Ewa Gałecka-Burdziak } \\
\text { Marek Góra }\end{array}$ \\
\hline $\mathrm{N}^{\circ} 169 / 17$ & $\begin{array}{l}\text { Flavia Coda Moscarola } \\
\text { Matteo Migheli }\end{array}$ \\
\hline $\mathrm{N}^{\circ} 168 / 17$ & $\begin{array}{l}\text { Cecilia Boggio } \\
\text { Flavia Coda Moscarola }\end{array}$ \\
\hline $\mathrm{N}^{\circ} 167 / 17$ & $\begin{array}{l}\text { Johannes G. Hoogeveen } \\
\text { Mariacristina Rossi } \\
\text { Dario Sansone }\end{array}$ \\
\hline
\end{tabular}

Labour Market Decisions of the Self-Employed in the Netherlands at the Statutory Retirement Age

Another look at Causes and Consequences of Pension Privatization Reform Reversals in Eastern Europe

Information and Financial Literacy for a Socially Sustainable NDC Pension System

The Italian Pension Gap: a Stochastic Optimal Control Approach

Social finance as a public policy instrument

Household Preferences For Socially Responsible Investments

Information and perceptions on pensions. The case of the 2011 Italian reform

Some financial implications of global warming: An empirical assessment

Retirement Rigidities and the Gap between Effective and Desired Labour Supply by Older Workers

Debt and Financial Vulnerability on the Verge of Retirement

Individual Heterogeneity and Pension Choices: How to Communicate an Effective Message?

Voting in the aftermath of a pension reform: the role of economic-financial literacy

How unemployed workers behave prior to retirement? A multi-state multiple-spell approach

Gender Differences in Financial Education: Evidence from Primary School

What is Good for the Goose is Good for the Gander? A Field Experiment on Gender, Language and Financial Market Participation

Leaving, staying or coming back? An analysis of the migration dynamics during the Northern Mali conflict

The full series is available at: $\underline{\text { http://www.cerp.carloalberto.org/category/publications/working-papers/ }}$ 